\title{
Microbial activity, methane production, and carbon storage in Early Holocene North Sea peats
}

\author{
Tanya J. R. Lippmann" ${ }^{1, \star}$, Michiel H. in 't Zandt ${ }^{2,3} \star$, Nathalie N. L. Van der Putten ${ }^{1}$, Freek S. Busschers ${ }^{4}$, \\ Marc P. Hijma ${ }^{5}$, Pieter van der Velden ${ }^{3}$, Tim de Groot ${ }^{6}$, Zicarlo van Aalderen ${ }^{1}$, Ove H. Meisel ${ }^{1,3}$, \\ Caroline P. Slomp ${ }^{3,7}$, Helge Niemann ${ }^{6,7,8}$, Mike S. M. Jetten ${ }^{2,3,9}$, Han A. J. Dolman ${ }^{1,3}$, and Cornelia U. Welte ${ }^{2,9}$ \\ ${ }^{1}$ Department of Earth Sciences, Vrije Universiteit Amsterdam, De Boelelaan 1085, 1081 HV Amsterdam, the Netherlands \\ ${ }^{2}$ Department of Microbiology, Institute for Water and Wetland Research, Radboud University, \\ Heyendaalseweg 135, 6525 AJ Nijmegen, the Netherlands \\ ${ }^{3}$ Netherlands Earth System Science Center, Utrecht University, Heidelberglaan 2, 3584 CS Utrecht, the Netherlands \\ ${ }^{4}$ TNO - Geological Survey of the Netherlands, Princetonlaan 6, 3508 TA Utrecht, the Netherlands \\ ${ }^{5}$ Department of Applied Geology and Geophysics, Deltares Research Institute, \\ Daltonlaan 600, 3584 BK Utrecht, the Netherlands \\ ${ }^{6}$ Department of Microbiology \& Biogeochemistry, Royal Netherlands Institute for Sea Research, \\ Landsdiep 4, 1797 SZ 't Horntje, the Netherlands \\ ${ }^{7}$ Department of Earth Sciences, Faculty of Geosciences, Utrecht University, \\ Princetonlaan 8a, 3584 CB Utrecht, the Netherlands \\ ${ }^{8}$ Centre for Arctic Gas Hydrate (CAGE), Environment and Climate, Department of Geosciences, \\ UiT The Arctic University of Norway in Troms $\varnothing$, Troms $\emptyset$, Norway \\ ${ }^{9}$ Soehngen Institute of Anaerobic Microbiology, Radboud University, \\ Heyendaalseweg 135, 6525 AJ Nijmegen, the Netherlands \\ These authors contributed equally to this work.
}

Correspondence: Tanya J. R. Lippmann (t.j.r.lippmann@vu.nl)

Received: 14 October 2020 - Discussion started: 5 November 2020

Revised: 13 July 2021 - Accepted: 16 August 2021 - Published: 11 October 2021

\begin{abstract}
Northern latitude peatlands act as important carbon sources and sinks, but little is known about the greenhouse gas (GHG) budgets of peatlands that were submerged beneath the North Sea during the last glacial-interglacial transition.

We found that whilst peat formation was diachronous, commencing between 13680 and 8360 calibrated years before the present, stratigraphic layering and local vegetation succession were consistent across a large study area. Large carbon stores were measured. In situ methane $\left(\mathrm{CH}_{4}\right)$ concentrations of sediment pore waters were widespread but low at most sites, with the exception of two locations.

Incubation experiments in the laboratory revealed molecular signatures of methanogenic archaea, with strong increases in rates of activity upon methylated substrate amendment. Remarkably, methanotrophic activity and the respective di-
\end{abstract}

agnostic molecular signatures could not be detected. Heterotrophic Bathyarchaeota dominated the archaeal communities, and bacterial populations were dominated by candidate phylum JS1 bacteria.

In the absence of active methanogenic microorganisms, we conclude that these sediment harbour low concentrations of widespread millennia-old $\mathrm{CH}_{4}$. The presence of large widespread stores of carbon and in situ methanogenic microorganisms, in the absence of methanotrophic microorganisms, holds the potential for microbial $\mathrm{CH}_{4}$ production if catalysed by a change in environmental conditions. 


\section{Introduction}

The expansion and submersion of northern latitude peatlands play a key role in global methane $\left(\mathrm{CH}_{4}\right)$ and carbon $(\mathrm{C})$ cycles (e.g. Charman et al., 2013; Morris et al., 2018). Globally, peatlands serve as long-term carbon sinks (Clymo et al., 1998; Gorham, 1991) that store more carbon than the world's forests combined despite covering only $3 \%$ of the world's surface land area (Xu et al., 2018). At the time of the Last Glacial Maximum (LGM), peatlands stored $600000 \mathrm{Tg}$ C worldwide (Yu et al., 2010). This estimate is calculated using ocean-basin-scale peat layer thickness and depth. Few in situ observations of peat deposit properties are available to quantify uncertainty.

Methane is globally the second most prevalent greenhouse gas (GHG), with emissions to the atmosphere amounting to $550-594 \mathrm{Tg} \mathrm{CH}_{4}$ each year (Saunois et al., 2020). Continental shelves and deltas are important sinks within the global carbon cycle (Oppo et al., 2020; Saunois et al., 2020) and are responsible for $80 \%-85 \%$ of oceanic carbon sequestration (Muller-Karger et al., 2005). Shelf regions contribute $\sim 75 \%$ of global ocean $\mathrm{CH}_{4}$ flux to the atmosphere, with estimates of seepage from oceanic shelves into bottom waters ranging between 6-12 $\mathrm{Tg} \mathrm{CH}_{4} \mathrm{yr}^{-1}$ (Weber et al., 2019) or 16$48 \mathrm{Tg} \mathrm{CH}_{4} \mathrm{yr}^{-1}$ (Judd et al., 2002). Reducing the uncertainties in these estimates requires further work at both regional and global scales (Oppo et al., 2020; Saunois et al., 2020). High $\mathrm{CH}_{4}$ concentrations in surface waters of continental shelves are due to $\mathrm{CH}_{4}$ inputs from estuaries and seafloor sediments, where methanogenesis is fuelled by high organic matter (OM) sedimentation (Carr et al., 2018; Zhuang et al., 2018). Methane entering the water column from the seafloor arrives by ebullition and pore water diffusion and is of either biogenic or thermogenic origin.

Variations in atmospheric $\mathrm{CH}_{4}$ are due, in part, to the changing extent of peatlands over glacial-interglacial periods (Frolking and Roulet, 2007). Triggered by postglacial sea level rise and, consequently, rising groundwater, peatlands (now basal peats) in the area between the Netherlands, the United Kingdom, and Denmark (now the North Sea) developed by the process of paludification in the Late Pleistocene and Early Holocene (Fig. 1a). During the Late Pleistocene and Early Holocene, strong glacio-isostatic adjustments (GIAs) resulted in the isostatic subsidence of the North Sea basin (Hijma et al., 2012; Vink et al., 2007), and, combined with rapid melting of polar ice sheets, high rates of sea level rise, up to $1-2 \mathrm{~cm} \mathrm{yr}^{-1}$ (Hijma and Cohen, 2019), gave rise to paludification, peatland development, and later peatland submersion (now basal peats).

Until now, only one vegetation record has documented the Late Pleistocene peatland ecosystem submerged beneath the North Sea basin (Wolters et al., 2010). The record began with an open birch (Betula) woodland, impacted by a carr vegetation, consisting mostly of Willow (Salix) due to early influences of paludification 10700 calibrated years (cal yr) before the present (BP). Subsequently, brackish reed (Phragmites), salt marsh vegetation with Chenopodiaceae, developed due to marine inundation ca. $9350 \mathrm{cal} \mathrm{yr} \mathrm{BP}$. The period of succession spanned 1300 years (Wolters et al., 2010). A high degree of peatland plant community variability results from the highly heterogeneous, irregular, and micro-ecosystem nature of peatlands (Clymo et al., 1998). It is likely that concurrent sea-level-independent terrestrialization occurred in isolated topographic features (e.g. local pools, valleys, streams), impacting local vegetation succession.

Microbial surveys of phylogenetic or functional gene markers have shown that bacterial community composition is generally distinct between different types of ecosystems, e.g. peatlands (Cadillo-Quiroz et al., 2006), estuarine and marine sediments (Purdy et al., 2002), tundra, and permafrost (Ganzert et al., 2007). Marine microbial communities are highly diverse and include many uncultured phylotypes (Fry et al., 2008). Community composition is often similar between ecosystems with common environmental parameters (Kim et al., 2018), but there is a lack of knowledge of the microbial processes contributing to the production of $\mathrm{CH}_{4}$ in submerged peat deposits globally and in the North Sea in particular.

Microbial activity plays a large role in the biological $\mathrm{CH}_{4}$ cycle and is estimated to be responsible for reducing annual seabed $\mathrm{CH}_{4}$ emissions to the atmosphere by $1-35 \mathrm{Tg} \mathrm{CH}_{4}$ (Saunois et al., 2020) or 8-65 $\mathrm{Tg} \mathrm{CH}_{4}$ (Reeburgh, 2007). In other words, $50 \%-90 \%$ of $\mathrm{CH}_{4}$ produced below ground is estimated to have been oxidized before reaching the atmosphere (Frenzell and Karofeld, 2000). Numerous studies have measured $\mathrm{CH}_{4}$ fluxes from present-day peatlands (e.g. Hendriks et al., 2007; Tiemeyer et al., 2016). Microbial $\mathrm{CH}_{4}$ production is performed by methanogens that carry out the final steps in the anaerobic degradation of OM. Methanogenesis is countered by the activity of methanotrophic microorganisms that oxidize $\mathrm{CH}_{4}$ to carbon dioxide $\left(\mathrm{CO}_{2}\right)$ using a variety of electron acceptors (in 't Zandt et al., 2018). The relative activity of methanotrophic vs. methanogenic microorganisms plays a determining role in $\mathrm{CH}_{4}$ emissions to the earth's atmosphere (Frenzell and Karofeld, 2000).

In most North Sea surface waters, $\mathrm{CH}_{4}$ concentrations are typically $<0.005 \mathrm{\mu M} \mathrm{L}^{-1}$ (Borges et al., 2016; Niemann et al., 2005). However, much higher $\mathrm{CH}_{4}$ concentrations $\left(1.1 \mu \mathrm{ML}^{-1}\right)$, among the highest in the world, are observed in the southern North Sea water column off the coast of Belgium (Borges et al., 2016). The release of $\mathrm{CH}_{4}$ from blowout craters linked to gas exploration could contribute to the high $\mathrm{CH}_{4}$ concentrations in the water column in the North Sea (Schneider von Deimling et al., 2015; Steinle et al., 2016), but the basin-scale impacts are uncertain (Rehder et al., 1998).

Despite extensive efforts to map these submerged peatland ecosystems (Treat et al., 2019; Xu et al., 2018), basal peats remain hard to reach, meaning accessing and measuring $\mathrm{CH}_{4}$ stores remain challenging, limiting in situ measure- 
A The submersion of North Sea peatlands and the current microbial habitats
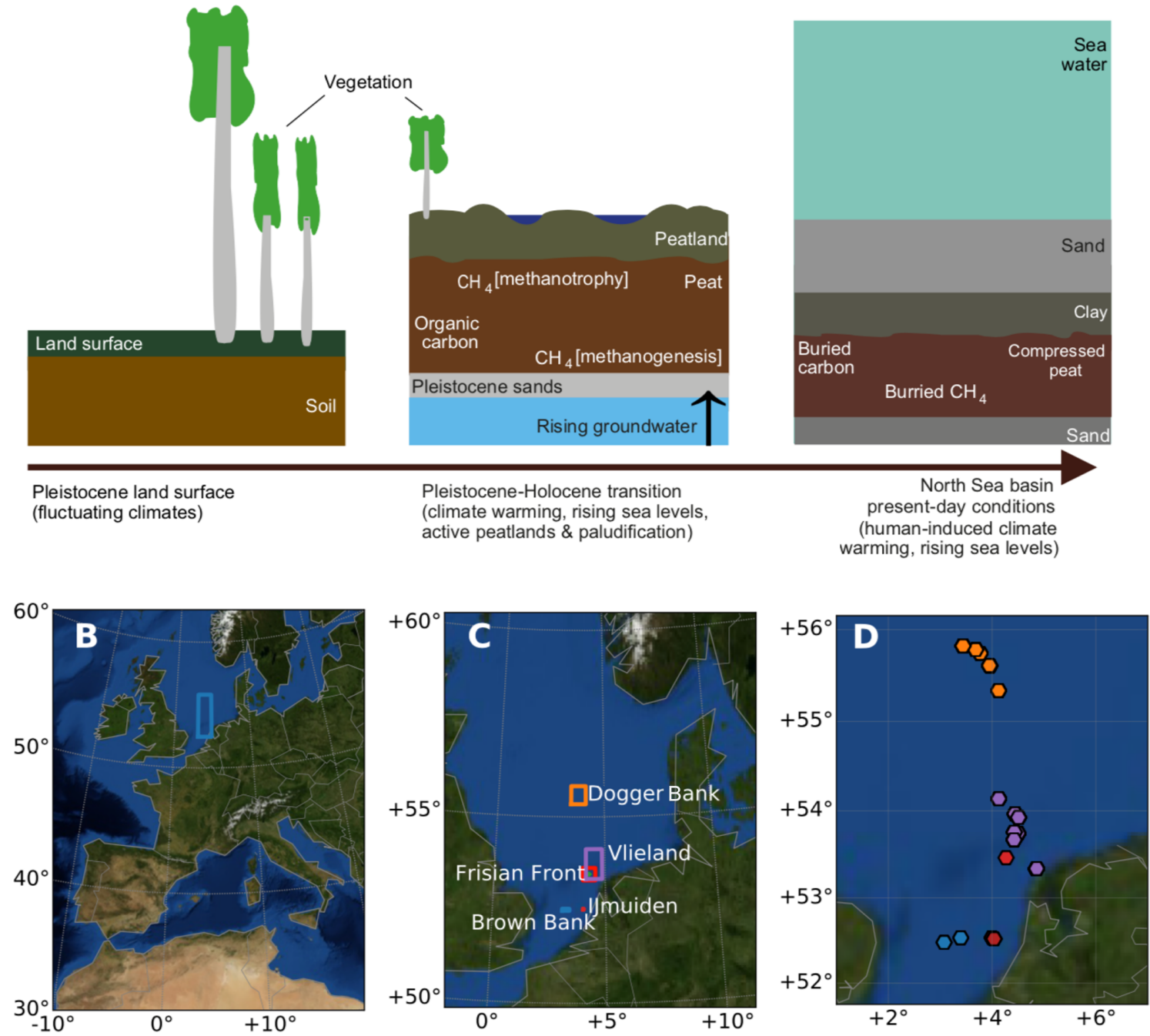

Figure 1. Peats submerged beneath the North Sea region of study. (a) Schematic of the evolution of processes that led to the conversion from the Pleistocene land surface to the buried marine peat sediments as they occur today. (b) The location of the sampling area within the context of western Europe. (c) The sampling areas and (d) the sampling sites in the North Sea, coloured according to the area names, plotted in panel (c). Panels (b), (c), and (d) were generated using Python's Basemap module, and the background map image uses NASA's Earth Observatory's Blue Marble: Next Generation.

ments (Dean et al., 2018). Consequently, these deposits are omitted from the global accounting of $\mathrm{C}$ and $\mathrm{CH}_{4}$ budgets of marine sediments (Saunois et al., 2020). Whilst the results of seismic surveys indicate large stores of naturally occurring biogenic $\mathrm{CH}_{4}$ within the North Sea basal peat deposits (Missiaen et al., 2002), the presence of $\mathrm{CH}_{4}$ has not been confirmed or quantified by in situ observations.

We derive the following hypotheses to describe the palaeopeat ecosystem submerged beneath the North Sea. Firstly, we hypothesize that $\mathrm{CH}_{4}$ is present within basal peat deposits beneath the North Sea. This is based on seismic signatures indicating large pockets of an unconfirmed gas in the submerged peat layer off the coast of Belgium. Secondly, considering that seismic surveys indicate that these gas pockets are without cracks and sealed off from underlying geological $\mathrm{CH}_{4}$ stores, we hypothesize that $\mathrm{CH}_{4}$ present in the basal peats is produced in the present day by methanogenic microorganisms. Thirdly, because the peatland ecosystem went through distinct changes from establishment to cessation influenced by groundwater paludification due to sea level rise during the Late Pleistocene and Early Holocene, we expect similar plant macrofossil sequences across the North Sea basin, according to the influence of sea level rise on local groundwater. Finally, we hypothesize that microbial populations will be influenced by carbon, mineral, and nutrient availability, depending on the plant macrofossil sequence, and we tentatively expect microbial populations to vary according to the plant macrofossil sequence. 


\section{Methods}

To provide a better understanding of submerged basal peats and their role in the global $\mathrm{C}, \mathrm{CO}_{2}$, and $\mathrm{CH}_{4}$ cycles, we present in situ $\mathrm{CH}_{4}$ concentrations and $\mathrm{OM}$ content of North Sea basal peat deposits. Plant macrofossil analysis was performed to determine plant community composition and describe the habitat available to microorganisms. Radiocarbon dating was carried out to determine the timing of peatland initiation and cessation. The 16S rRNA gene amplicon sequencing was performed to determine microbial diversity, and batch incubation experiments were conducted to investigate actual and potential microbial $\mathrm{CH}_{4}$ cycle activity in the submerged peat deposits. We compare the results across sites.

\subsection{Study area}

The study region (Fig. 1b) spans $150 \mathrm{~km}$ east to west, bordering the United Kingdom $\left(3^{\circ} \mathrm{E}\right)$ and the barrier islands of the Netherlands $\left(5^{\circ} \mathrm{E}\right)$, and $371 \mathrm{~km}$ north to south, extending from the latitude of 52 to $56^{\circ} \mathrm{N}$. This region includes the Dogger Bank, Frisian Front, and the Brown Bank, with ocean depths ranging from 19 to $60 \mathrm{~m}$. A total of 34 cores were collected across 22 sites (see Supplement Table S1 for the location and analysis details of all cores and sites). To carry out multiple sampling procedures, we used more than one core per site with the aim of comparing results across sites, not within sites. Each sampling method uses one core per site. Cores, sites, and sampling are documented in Table S1. In this paper, we refer to the site names except in places where the specific core number is relevant. The sites were named according to nearby shipwrecks using EMODnet (EMODnet, 2018) with the exception of the Darci site.

Methane measurements were performed at all sites. Four sites in the Vlieland (Vittorio, Max Gundelach, Senator Westphal SW, Westland) and Dogger Bank (Dorthea Shallow SW, Dorthea SSW, Dorthea NW, Fredricksborg NE) regions were chosen for microbial sequencing analysis and microbial activity studies, respectively. Loss on ignition (LOI) was performed on these eight sites. These sites are a focus of this paper. Two sites were chosen for plant macrofossil analysis (Vittorio and Fredricksborg NE) and radiocarbon dating. All cores were photographed and texturally described at the facilities of TNO-GDN (Geological Survey of The Netherlands; Bosch, 2000) and are available at https://www.dinoloket.nl.

\subsection{Sediment sampling}

Short vibrocores (3-4.5 m) were collected during two separate cruises in June 2017 and July 2018 on board the research vessel Pelagia. Before the cruise, digital maps of peat occurrences in the southern North Sea were prepared using the DINO digital database of the TNO-GDN (Van Der Meulen et al., 2013). Based on these maps, areas were selected for geophysical research using sub-bottom profiler and sparker systems. The seismic profiles were directly interpreted on board to identify the presence and depth of basal peat beds. The seismic data were used to select sampling sites from a range of water depths and latitudes and within the maximum penetration depth of the vibrocorer ( $4.5 \mathrm{~m}$ below the seabed). At each site, two or three cores were collected. Before sampling, or after (in the case of $\mathrm{CH}_{4}$ sampling only), the cores were cut into $1 \mathrm{~m}$ sections. From one core, $\mathrm{CH}_{4}$ samples were taken as soon as the core was on deck. One of the three recovered cores was cut lengthways following recovery. Sediment for molecular analysis was sampled immediately after opening the core sections and frozen at $-80^{\circ} \mathrm{C}$ until further analysis. Subsequently, pore water samples were collected, and sedimentary samples were taken to determine porosity. All sections were stoppered, sealed at the base and the top, and stored in a refrigerated container $\left(4^{\circ} \mathrm{C}\right)$.

\subsection{Sediment analysis}

Loss on ignition (LOI) analysis was performed at $2 \mathrm{~cm}$ resolution within peat layers and $10 \mathrm{~cm}$ resolution in non-peat layers at the eight sites corresponding to the sites of the molecular analyses. Organic matter (OM) content (in \%) was measured using a Leco ${ }^{\circledR}$ TGA701 thermogravimetric analyser at Vrije Universiteit Amsterdam. Dried samples were crushed and weighed, and the mass loss was measured stepwise during the heating of the samples from room temperature to $1000^{\circ} \mathrm{C}$. Here, we present the mass loss at $330^{\circ} \mathrm{C}$ (LOI330) and $550^{\circ} \mathrm{C}$ (LOI550). Fixed volume subsamples $\left(42.39 \mathrm{~cm}^{3}\right)$ were used to measure volumetric water content, bulk density, and porosity $\left(\mathrm{cm}^{3} \mathrm{~cm}^{-3}\right)$. These samples were saturated with deionized water, weighed, dried at $60^{\circ} \mathrm{C}$ for $5 \mathrm{~d}$, and then re-weighed. The bulk density of the sediment was calculated by dividing the volume of the dried sediment by the dry mass. Total pore space (porosity, $\varphi$ ) was calculated by subtracting the measured volumes of water from the original fixed sample volume. The total $\mathrm{C}$ pool was estimated using Eq. (1), a general equation used to estimate peatland carbon stocks (Sheng et al., 2004). To estimate the total $\mathrm{CH}_{4}$ pool, Eq. (2) is an adaptation of Eq. (1). The minimum and maximum peat thicknesses provide uncertainty estimates of the total $\mathrm{C}$ and $\mathrm{CH}_{4}$ pools, respectively.

$$
\begin{aligned}
& C_{\text {peat }}=\sum A \times \bar{D} \times \bar{\rho} \times \overline{\mathrm{OM}} \times \mathrm{OM}_{C}, \\
& \mathrm{CH}_{4_{\text {peat }}}=\sum A \times \bar{D} \times \overline{\mathrm{CH}_{4}(\varnothing)},
\end{aligned}
$$

where $A, D, \rho$, and $\mathrm{OM}_{C}$ represent the area, peat thickness, bulk density, and OM to $C$ conversion factor (for this peatland type), respectively. $\mathrm{CH}_{4}$ concentration is calculated considering porosity $(\varnothing)$. 


\subsection{Methane sampling}

The sampling and measurement of $\mathrm{CH}_{4}$ concentrations followed standard protocols for headspace sampling and analysis of marine sediments (Egger et al., 2015, 2017; Reeburgh, 2007). Prior to coring, the core liner was pre-drilled with $2 \mathrm{~cm}$ diameter holes at $10 \mathrm{~cm}$ resolution and taped to be gastight. Upon retrieval and working with speed, the top and bottom of the core were sealed immediately, and custommade metal syringes were inserted into each taped hole. A total of $10 \mathrm{~mL}$ of sediment was extracted and deposited into a $65 \mathrm{~mL}$ glass bottle filled with a saturated sodium chloride $(\mathrm{NaCl})$ solution. Each bottle was sealed with a butyl rubber stopper and a screw cap and stored upside down at $4{ }^{\circ} \mathrm{C}$. In the laboratory of the Vrije Universiteit Amsterdam, the $\mathrm{CH}_{4}$ bottles were prepared for analysis. A total of $10 \mathrm{~mL}$ of nitrogen $\left(\mathrm{N}_{2}\right)$ was injected into each $\mathrm{CH}_{4}$ bottle (with a needle inserted through the septum, allowing excess water to escape) to create a headspace. From this headspace, a subsample was collected with a gas-tight syringe and injected into a Thermo Finnigan TRACETM gas chromatograph (equipped with a flame ionization detector - FID) at Utrecht University. Methane concentrations were calculated using calibrations from standard gases and measured sediment porosity.

\subsection{Pore water analysis}

Samples for pore water analysis were extracted using $5 \mathrm{~cm}$ long porous polymer soil moisture sampler rhizons (Rhizosphere Research Products B.V., the Netherlands) at $10 \mathrm{~cm}$ resolution and stored at $4{ }^{\circ} \mathrm{C}$. The samples were acidified with $1 \% \mathrm{HNO}_{3}$ and analysed by inductive coupled plasma optical emission spectrometry (ICP-OES) for $\mathrm{Al}, \mathrm{Ca}, \mathrm{Fe}, \mathrm{K}$, $\mathrm{Mg}, \mathrm{Mn}, \mathrm{Na}, \mathrm{P}, \mathrm{S}, \mathrm{Si}$, and Zn (iCap 6300, Thermo Scientific, Waltham, MA) and continuous flow analysis (CFA) for $\mathrm{NO}_{3}^{-}$, $\mathrm{NH}_{4}^{+}, \mathrm{PO}_{4}^{3-}, \mathrm{Na}^{+}, \mathrm{K}^{+}$, and $\mathrm{Cl}^{-}(\mathrm{Bran}+$ Luebbe AutoAnalyzer, SPX Flow, Norderstedt, Germany; Seal Analytical AutoAnalyzer 3, Seal Analytical, Southampton, UK; Table S2).

\subsection{Molecular analyses}

Four cores in the southern North Sea were selected for $16 \mathrm{~S}$ rRNA amplicon sequencing, and four cores from the Dogger Bank area were selected for microbial activity studies. Unfortunately, the cores from the first sampling expedition did not provide enough material to perform both sequencing and the incubation experiments. Therefore, we chose to divide the microbial experiments over multiple sites in order to obtain the maximum amount of information possible whilst taking the experimental constraints into consideration.

\subsubsection{DNA isolation}

Samples for DNA isolation were immediately extracted aseptically upon sampling. Samples were stored at $-20^{\circ} \mathrm{C}$ until further analysis. DNA was extracted in duplicate per sam- ple using the Qiagen DNeasy PowerSoil Kit (Qiagen, Venlo, the Netherlands) following the manufacturer's instructions with the following modifications: the initial PowerBead Tube vortex step was carried out using a TissueLyser LT (Qiagen, Venlo, the Netherlands) at $50 \mathrm{~Hz}$ for $10 \mathrm{~min}(\mathrm{~min})$, and the primary centrifugation step was increased to $1 \mathrm{~min}$ at $10000 \times g$. DNA was eluted with $2 \times 30 \mu \mathrm{L}$ of sterile Milli$\mathrm{Q}$ incubated for $2 \mathrm{~min}$ at room temperature prior to centrifugation. The second elution centrifugation step was carried out for $1 \mathrm{~min}$ at $10000 \times g$. DNA quality was assessed by agarose gel electrophoresis, spectrophotometrically using a NanoDrop 1000 (Invitrogen, Thermo Fisher, Carlsbad, CA, USA) and fluorometrically using the Qubit ${ }^{\mathrm{TM}}$ dsDNA HS Assay Kit (Invitrogen, Thermo Fisher, Carlsbad, CA, USA) according to the manufacturer's instructions. Duplicate samples with the highest yield and quality were selected for downstream application.

\subsubsection{Amplicon sequencing and analysis}

For DNA purification, the QIAquick PCR Purification Kit was used (Qiagen, Venlo, the Netherlands). For DNA amplification, a two-step amplicon sequencing protocol was used. In the first step, the V3-V4 region of the bacterial 16S rRNA gene was amplified using the universal primers Bac341F (5'-CCTACGGGNGGCWGCAG-3') (Herlemann et al., 2011) and Bac785R (5'-GACTACHVGGGTATCTAATCC$3^{\prime}$ ) (Klindworth et al., 2013) for 30 cycles. Archaeal 16S rRNA genes were amplified with the universal archaeal primers Arch349F (5'-GYGCASCAGKCGMGAAW$3^{\prime}$ ) (Takai and Horikoshi, 2000) and Arch806R (5'GGACTACVSGGGTATCTAAT-3') (Takai and Horikoshi, $2000)$ for 30 cycles. The total PCR reaction volume was $25 \mu \mathrm{L}$ with $1 \mu \mathrm{L}$ forward and $1 \mu \mathrm{L}$ reverse primer $(20 \mu \mathrm{M})$, $1 \mu \mathrm{L}$ template, $12.5 \mu \mathrm{L} 2 \times$ concentrated SYBR ${ }^{\text {TM }}$ Green PCR Master Mix (Thermo Fisher, Carlsbad, CA, USA), and $9.5 \mu \mathrm{L}$ sterile Milli-Q. All primers were purchased from Biolegio (Biolegio B.V., Nijmegen, the Netherlands).

The following cycling parameters were used for polymerase chain reaction (PCR): initial denaturation for $10 \mathrm{~min}$ at $98^{\circ} \mathrm{C} ; 25 / 30$ cycles of denaturation for $1 \mathrm{~min}$ at $95^{\circ} \mathrm{C}$, annealing for $1 \mathrm{~min}$ at $60^{\circ} \mathrm{C}$, and elongation for $2 \mathrm{~min}$ at $72^{\circ} \mathrm{C}$; and a final elongation step for $10 \mathrm{~min}$ at $72^{\circ} \mathrm{C}$. The primers were tested in an annealing temperature gradient experiment, and $60^{\circ} \mathrm{C}$ was determined as the optimal temperature for initial amplification. The annealing temperature of $60^{\circ} \mathrm{C}$ was selected because we observed intense bands of the correct amplicon and no observable primer dimers at this temperature. PCR products were purified using the QIAquick PCR Purification Kit (Qiagen, Venlo, the Netherlands) in two elution steps. A $20 \mu \mathrm{L}$ aliquot of $55^{\circ} \mathrm{C}$ Milli-Q water was added to the spin column and incubated for 2 min prior to centrifugation. Next, the eluate was added to the spin column, incubated at $55^{\circ} \mathrm{C}$ for $2 \mathrm{~min}$, and centrifuged again as described in the manual. The purified PCR products were used in a sec- 
ond 10-cycle nested PCR performed with ion torrent adapters using the PCR protocol described above. After purification with the QIAquick PCR Purification Kit as described earlier, the PCR products were used for library preparation and sequencing steps according to the manufacturer's instructions (Life Technologies, Carlsbad, CA, United States).

Samples were sequenced on an Ion 318 Chip Kit v2 (Thermo Fisher, Waltham, MA, USA). Amplicon sequences were quality checked for chimeras and clustered into operational taxonomic units (OTUs) with a $97 \%$ identity cut-off value using the 454 SOP (http://www.mothur.org/, last access: 18 May 2020) (Schloss et al., 2009) with ion torrent modified protocols in May 2018. Chimeras were checked with the UCHIME algorithm version 4.2.40 (Edgar et al., 2011), and singletons were removed (Fig. S1). Taxonomy was assigned according to the SILVA v132 database using the default, "mothur", taxonomy assigner (Schloss et al., 2009). Data visualization was performed using the "vegan" package (version 2.5-6) in R (Oksanen et al., 2019). All alpha diversity indices were calculated with the OTU-based alpha diversity analysis tool summary.single of "mothur". Non-metric dimensional scaling (NMDS) plots were prepared in R using the "vegan" and "MASS" (version 7.3-5.0) packages after pre-filtering of non-abundant OTUs (Venables and Ripley, 2002). OTUs with a sum of $\leq 1$ per sequencing dataset were removed from the OTU table. NMDS ordination was performed with the metaMDS function of "vegan". Data were processed by square root transformation and Wisconsin double standardization. We want to stress that biases associated with PCR-based amplicon studies can result in an observed absence of specific microbial clades and results need to be interpreted with care.

\subsubsection{PCR quantification and quantitative polymerase chain reaction}

The 16S rRNA gene copy numbers were quantified with the archaeal and bacterial primers described above, except that for bacterial quantification, the primer Bac806R (5'-GGACTACHVGGGTWTCTAAT-3') (Caporaso et al., 2012) was used. Quality and size checks were performed by agarose gel electrophoresis. All quantitative polymerase chain reaction (qPCR) reactions were performed using PerfeCTa Quanta master mix (Quanta Bio, Beverly, MA) and 96-well optical PCR plates (Bio-Rad Laboratories B.V., Veenendaal, the Netherlands) with optical adhesive covers (Applied Biosystems, Foster City, CA). All reactions were performed on a C1000 Touch ${ }^{\mathrm{TM}}$ thermal cycler equipped with a CFX96 Touch $^{\mathrm{TM}}$ Real-Time PCR Detection System (BioRad Laboratories B.V., Veenendaal, the Netherlands); a maximum of $1 \mathrm{ng}$ of DNA template was used per reaction. Negative controls were prepared for each run by replacing the template with sterile Milli-Q water. Standard curves were constructed with a 10-fold serial dilution of a quantified copy number of pGEM $^{\circledR}$ T Easy plasmids containing inserted Illu- mina primer PCR fragments of the archaeal and bacterial 16S rRNA genes (Promega, Madison, WI) (de Jong et al., 2018). All qPCR data were analysed using Bio-Rad CFX Manager version 3.0, using the default settings for defining the detection threshold and efficiencies (Bio-Rad Laboratories B.V., Veenendaal, the Netherlands). All qPCR efficiencies were above $90 \%$.

\subsection{Incubation experiments}

Sediment cores for the activity study were drilled on 27 and 28 June 2018 and stored for 10 months at $4{ }^{\circ} \mathrm{C}$ until further processing. Material was taken aseptically from the carbon-rich (dark black/brown) peat layer and stored in sterile $50 \mathrm{~mL}$ falcon tubes kept on ice at $4{ }^{\circ} \mathrm{C}$ during transport. A total sediment slurry volume of $1.5 \mathrm{~L}$ was obtained by mixing $750 \mathrm{~g}(0.5 \mathrm{~L} \mathrm{Vol})$ of peat with artificial seawater $\left(0.546 \mathrm{M} \mathrm{Cl}^{-}, \quad 0.469 \mathrm{M} \mathrm{Na}^{+}\right.$, $0.0528 \mathrm{M} \mathrm{Mg}^{2+}, \quad 0.0282 \mathrm{M} \mathrm{SO}_{4}^{2-}, \quad 0.0103 \mathrm{M} \mathrm{Ca}^{2+}$, $0.0102 \mathrm{M} \mathrm{K}^{+}, \quad 0.0012 \mathrm{MCO}_{3}^{2-}, \quad 0.000844 \mathrm{M} \mathrm{Br}^{-}$, $0.000091 \mathrm{M} \mathrm{Sr}^{2+}, \quad 0.000416 \mathrm{MBB}^{-}, \quad 0.00935 \mathrm{M} \mathrm{NH}_{3}^{+}$, $0.00367 \mathrm{M} \mathrm{PO}_{4}^{3-}$ ) (Dickson and Goyet, 1994) amended with $1 \mathrm{mLL}^{-1} 1000 \times$ trace element solution SL-10 with $24 \mathrm{mg} \mathrm{L}^{-1} \mathrm{CeCl}_{3} \cdot 7 \mathrm{H}_{2} \mathrm{O}, 30 \mathrm{mg} \mathrm{L}^{-1} \mathrm{Na}_{2} \mathrm{SeO}_{3} \cdot 5 \mathrm{H}_{2} \mathrm{O}$, and $40 \mathrm{mg} \mathrm{L}^{-1} \mathrm{Na}_{2} \mathrm{WO}_{4} \cdot 2 \mathrm{H}_{2} \mathrm{O}$ (DSMZ) and adjusted to $\mathrm{pH}$ 7.0. Under continuous mixing, $50 \mathrm{~mL}$ sludge aliquots were transferred to $120 \mathrm{~mL}$ sterile glass serum bottles. The bottles were sealed with airtight butyl rubber stoppers and capped with open top aluminium crimp caps. All incubations were carried out in triplicate per condition.

Methanogenic incubations were carried out anoxically with acetate $(20 \mathrm{mM}), \mathrm{H}_{2} / \mathrm{CO}_{2}\left(20 \mathrm{mM} \mathrm{H}_{2}\right.$ with $20 \% \mathrm{CO}_{2}$ in headspace), $\mathrm{H}_{2}$ / methanol (10 $\left.\mathrm{mM} \mathrm{H}_{2}, 10 \mathrm{mM} \mathrm{MeOH}\right)$, and trimethylamine $(20 \mathrm{mM})$. For methoxydotrophic methanogenesis, incubations were started with methoxyphenol (MPH; $3 \mathrm{mM})$ and trimethylbenzoate $(3 \mathrm{mM})$. For sulfate-dependent methanotrophy, samples were incubated with $28.2 \mathrm{mM}$ sulfate, the concentration present in the artificial seawater, and $5 \%(\sim 2 \mathrm{mM}){ }^{13} \mathrm{C}_{-}-\mathrm{CH}_{4}$. The anoxic control incubations were unamended. Anoxic conditions were created by three $15 \mathrm{~min}$ cycles of vacuuming and subsequent gassing for $3 \mathrm{~min}$ with 1 bar overpressure. The overpressure was removed before starting the incubations. The gas mixture contained $80 \% \mathrm{~N}_{2}$ and $20 \% \mathrm{CO}_{2}$ except for the incubations for hydrogen-dependent methylotrophic methanogenesis, which were gassed with $100 \% \mathrm{~N}_{2}$. To remove trace oxygen, $0.5 \mathrm{~mL}$ of $150 \mathrm{~g} \mathrm{~L}^{-1} \mathrm{~L}$-cysteine $\mathrm{HCl}$ and $0.5 \mathrm{~mL}$ of $150 \mathrm{~g} \mathrm{~L}^{-1} \mathrm{Na}_{2} \mathrm{~S}$ were added. To inhibit excessive growth of sulfate-reducing bacteria, a sterile sodium molybdate solution was added at a final concentration of $1.5 \mathrm{mM}$ to all incubations with $\mathrm{H}_{2}$ (Banat Nedwell and Balba, 1983). A new dose of $10 \mathrm{mM} \mathrm{H}_{2}$ was added to the $\mathrm{H}_{2} / \mathrm{CO}_{2}$ incubations at 30 and $49 \mathrm{~d}$ of incubation and to the $\mathrm{H}_{2} /$ methanol incubations at 35 and $49 \mathrm{~d}$ of 
incubation. A second dose of $10 \mathrm{mM} \mathrm{MeOH}$ was added to the $\mathrm{H}_{2}$ / methanol incubations at $63 \mathrm{~d}$ of incubation.

For aerobic methanotrophic incubations, air was used as the headspace and amended with $10 \mathrm{mM} \mathrm{CH}_{4}$. Oxic control incubations contained only air. All substrate concentrations were calculated based on a liquid volume of $50 \mathrm{~mL}$ and assuming that all of the substrate dissolved over time.

For substrate consumption rates, the per cubic centimetre substrate conversions were calculated by dividing the total substrate conversion numbers by $16.67 \mathrm{~cm}^{3}$, which corresponds to the quantity of compacted peat sediment inoculated per batch incubation.

\section{Substrate and product analysis}

Gas samples $(50 \mu \mathrm{L})$ were withdrawn with a gas-tight glass syringe (Hamilton, Reno, NE) and injected into an HP 5890 gas chromatograph (Hewlett Packard, Palo Alto, CA) equipped with a Porapak Q 100/120 mesh (Sigma Aldrich, Saint Louis, MI) and a flame ionization detector (FID) for $\mathrm{CH}_{4}$ detection and a thermal conductivity detector (TCD) for measuring $\mathrm{H}_{2}, \mathrm{CH}_{4}$, and $\mathrm{CO}_{2}$ simultaneously using $\mathrm{N}_{2}$ as the carrier gas. An Agilent 6890 series gas chromatograph coupled to a mass spectrometer (Agilent, Santa Clara, CA) equipped with a Porapak $\mathrm{Q}$ column heated at $80^{\circ} \mathrm{C}$ with $\mathrm{He}$ as the carrier gas was used for measurements of ${ }^{13} \mathrm{CO}_{2}$, ${ }^{13} \mathrm{CH}_{4}$, and $\mathrm{O}_{2}$.

\subsection{Plant macrofossil analysis}

Two sites, the Max Gundelach site and the Fredricksborg NE site, were selected for plant macrofossil analysis. The Max Gundelach site is in the southern North Sea near the coast of the Netherlands $\left(53^{\circ} 20^{\prime} \mathrm{N}, 4^{\circ} 51^{\prime} \mathrm{E}\right)$, and the Fredricksborg $\mathrm{NE}$ site is in the Dogger Bank region $\left(55^{\circ} 49^{\prime} \mathrm{N}, 3^{\circ} 26^{\prime} \mathrm{E}\right)$.

The Max Gundelach site was analysed with low sample resolution but high taxonomic resolution, showing the main peat components and an overview of the less abundant taxa. As the less abundant taxa were, in this research, not highly relevant, we analysed the Fredricksborg NE site with high sample resolution but low taxonomic resolution, showing only the main peat components. The sites can be compared based on the main peat components.

From the Max Gundelach core, eight samples (slices with a thickness of $1 \mathrm{~cm}$ or, in two cases, $2 \mathrm{~cm}$ and a volume ranging from 8 to $11 \mathrm{~cm}^{3}$ ) for plant macrofossils were taken every $10 \mathrm{~cm}$. From the Fredricksborg NE core, 15 subsamples were taken with a resolution ranging from 1 to $4 \mathrm{~cm}$ and volumes ranging from 3 to $8 \mathrm{~cm}^{3}$. The samples were heated near the boiling point in $5 \% \mathrm{NaOH}$ solution and then gently washed through a $150 \mu \mathrm{m}$ mesh sieve with tap water. After sieving, the plant macrofossils were stored in a known volume of water. The sample material was systematically examined at 15 to $40 \times$ magnification using a stereomicroscope.
The main peat components (monocot epidermis, brown mosses, Sphagnum spp.) of both cores were quantified based on the quadrat and leaf count (QLC) method (Barber et al., 1994, 2003) using 15 averaged quadrat $(1 \times 1 \mathrm{~cm})$ counts under low power $(10 \times)$ magnification using a $10 \times 10$ square grid graticule. The main peat components were expressed as percentages $(\%)$. The complete samples were scanned for quantification of the less abundant macrofossils, in the case of the Max Gundelach core, and seeds, fruits, leaves, and fragments of mosses were picked out, counted, and expressed as concentrations per unit of volume. Rare taxa are reported as presence. Preservation of the peat deposits was estimated qualitatively during analysis based on the preservation of the macro fossils: poorly preserved $(+)$, intermediately preserved $(++)$, and well preserved $(+++)$. The diagram was constructed with Tilia version 1.7.16 (Grimm, 2004).

\subsection{Radiocarbon dating}

For radiocarbon dating purposes, the top and bottom $1 \mathrm{~cm}$ of the peat layers were sieved and searched for autochthonous terrestrial plant macrofossils or, in the absence of such fossils, charcoal (Hijma and Cohen, 2010). If a $1 \mathrm{~cm}$ thick section did not contain enough macrofossils, material from the subsequent centimetre was added. The selected macrofossils were sent to the Centre for Isotope Research (Groningen, the Netherlands) for AMS radiocarbon dating. All radiocarbon ages were calibrated using OxCal 4.3 software (Bronk Ramsey, 2009) with the INTCAL13 curve (Reimer et al., 2013).

\section{Results}

\subsection{Basal peats vary in thickness, formed on Pleistocene sands, capped by marine clays}

The localized nature of this palaeo-landscape is apparent in the lithostratigraphic differences observed between and within sites (Fig. 2). The four sites (Fig. 2a-d) chosen for 16S rRNA gene-based sequencing and the four sites (Fig. 2ef) used in incubation experiments to investigate the potential role of in situ microbial communities are a focus of the results. Peat was recovered at all sites except Easting Down, Stormvogel, and the Darci site. Whilst seismic signals at the Easting Down and Stormvogel sites indicated the presence of a peat layer, the peat was beyond the range of the vibrocorer at the Easting Down and was a peat-like gyttja (highly organic lacustrine sediment) at the Stormvogel site. At all other sites, peat deposits lie upon Pleistocene sands, capped by marine clays. At some sites, the overlying clay layer was stratified with marine sands (i.e. Dorthea Shallow SW, Dorthea SSW, Dorthea NW, Fredricksborg NE; Fig. 2e$\mathrm{h}$, respectively). Pleistocene sands lie 2-4 $\mathrm{m}(\mathrm{m})$ beneath the seafloor (m b.s.f.) in the southern North Sea and 1-3 m b.s.f. in the Dogger Bank region, capped by basal peat layers 80 
120 and $10-30 \mathrm{~cm}$ thick in the southern North Sea and Dogger Bank regions, respectively.

Non-erosive contact transitions exist between the peat layer and both the immediate upper and lower sedimentary layers at 17 of the 22 sites. In most cases, the peat was covered by a clay layer that formed under lagoonal, low-energy conditions. However, some cores show erosional contacts at the top of the peat beds - i.e. Fredricksborg NE (Fig. 2h), Fredricksborg NW, and Dorthea NW sites (Fig. 2g) - that may be linked to marine transgressions in the area, likely related to waves or tidal currents. The clay sediment directly above the peat layer at the Vittorio site, approximately $1 \mathrm{~m}$, was the thickest clay deposit retrieved in this study. In comparison, the nearby Max Gundelach site has clay deposits capping the peat that are $\sim 35 \mathrm{~cm}$ thick. At the other sites, the clay deposits capping the peat layer range from 5 to $50 \mathrm{~cm}$. Max Gundelach, a southern site in the Vlieland region, and Fredricksborg NE, a northern site in the Dogger Bank region, were determined to be representative of the local onset and termination of peat development, respectively, and were therefore selected for macrofossil analysis.

\subsection{Methane concentrations are low, widespread with localized high concentrations}

The average $\mathrm{CH}_{4}$ concentration of the sediment pore waters was $2.1 \mu \mathrm{mol} \mathrm{L}{ }^{-1}$, with a maximum concentration of $32.8 \mu \mathrm{mol} \mathrm{L}-1$ at the Vittorio site (Fig. 3). A total of 10 sites had $\mathrm{CH}_{4}$ concentrations lower than the study average, i.e. $<2 \mu \mathrm{mol} \mathrm{L}{ }^{-1}$ : TX24, Theodor, Mahren S, Easting Down, Leda, Dorthea Shallow SW, Dorthea NNW, Dorthea NW, Fredricksborg NE, and Easting Down. A total of 10 sites had $\mathrm{CH}_{4}$ concentrations similar to or above the study average, i.e. $>2 \mu \mathrm{mol} \mathrm{L}^{-1}$ : Vittorio, Max Gundelach, U21, Senator Westphal, Westland, Fredricksborg NW, Stormvogel, Dorthea Deep SW, Darci site, and Dorthea Shallow SW. One of the two cores retrieved from the Dorthea Shallow SW site had low $\mathrm{CH}_{4}$ concentrations, while the second had high $\mathrm{CH}_{4}$ concentrations. Overall, we found approximately equal numbers of sites with high and low $\mathrm{CH}_{4}$ concentrations, across varying thicknesses of peat layers (Fig. 3), latitudes, and depths beneath the seafloor (Table S1).

\subsection{Peatland establishment and cessation}

At the Max Gundelach site in the Vlieland region, radiocarbon dating revealed that active peat formation prevailed for approximately 2000-3000 years longer than at the Fredricksborg NE site in the Dogger Bank region (Table 1). The basal peat layer of the Max Gundelach site was approximately $85 \mathrm{~cm}$ thick, and radiocarbon dating revealed that an active peatland persisted for 3470 years between 11760 and $8290 \mathrm{cal}$ yr BP, a far longer period than at the Fredricksborg $\mathrm{NE}$ site where the peat layer was only $10 \mathrm{~cm}$ thick. At the Fredricksborg NE site, dating indicated that an active peat- land persisted during an earlier and shorter 800 year period between 13680 and $12880 \mathrm{cal} \mathrm{yr} \mathrm{BP.} \mathrm{Macrofossil} \mathrm{analysis}$ denoted that peat accumulation occurred through paludification due to a rising water table at sites.

\subsubsection{Local vegetation succession in the southern North Sea}

At the Max Gundelach site, wet terrestrial vegetation was present at the start of peat accumulation $11760 \mathrm{cal} \mathrm{yr} \mathrm{BP,}$ with the presence of Carex spp. (Fig. 4a). A certain degree of open water was present as remains of invertebrates (Chironomid head capsules, Cladocera) together with Characeae oospores were found. These green algae are characteristic of lake waters in pioneer conditions with inputs of minerogenic material (Mauquoy and Van Geel, 2007) and therefore indicative of eutrophic conditions.

At $180 \mathrm{~cm}$ beneath the seabed, Cladocera resting eggs were found, suggesting harsher conditions for these invertebrates. All other open-water taxa disappeared. From a depth of $170 \mathrm{~cm}$ onward, the environment became nutrient-poor, as evidenced by the dominance of Sphagnum magellanicum. $S$. magellanicum is an important contributor to ombrotrophic peat bogs with a constant water table (Siebel and During, 2006). Remains of woody plants, in the form of leaf scars, and charcoal were also present at this depth. This indicates the presence of vascular plants during peatland growth. $S$. magellanicum declined and the brown moss Tomentypnum nitens, a species no longer occurring in the Netherlands, became the main peat-forming component at $160 \mathrm{~cm}$ depth. $T$. nitens is an indicator species of mineral-rich fens, highlighting a change from nutrient-poor to nutrient-rich conditions. The presence of $T$. nitens indicates that calcium and nutrientrich groundwater were seeping into the terrestrial environment (Bohncke et al., 1984; van Geel et al., 2020; Hedenäs and Kooijman, 1996). From $150 \mathrm{~cm}$ depth onward, T. nitens was replaced by Warnstorfia sarmentosa and Drepanocladus sp. Both species are brown mosses, further indicating a transition to wet mesotrophic conditions. Carex sp. (sedges) rootlets were found in the top of the peat sequence.

\subsubsection{Local vegetation succession at Dogger Bank}

In the lower part of the Fredricksborg NE core (Fig. 4b), from $191 \mathrm{~cm}$ onward, a change from nearly purely minerogenic substrate (LOI550 is ca. $1 \%$ ) to slightly higher LOI550 values (ca. 6\%, Fig. S2) points to the presence of a sparse pioneer vegetation. In the three lower samples, megaspores of Selaginella selaginoides were found. S. selaginoides is a heliophilous (needing/tolerating a high level of direct sunlight) circumpolar boreal-montane species growing in damp neutral to alkaline conditions, including dune-slacks, fens, flushes, mires, and short upland grassland (Tobolski and Ammann, 2000). In northern Scandinavia it occurs in mires, at lake margins, and in damp heath meadows (Bjune et al., 


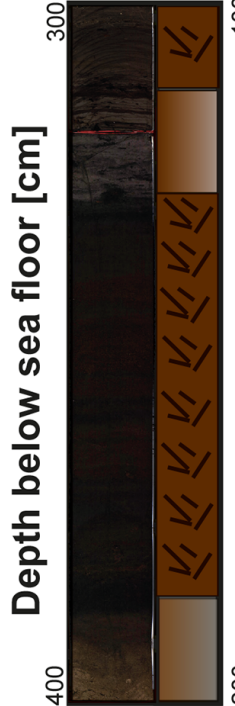

(a) Vittorio

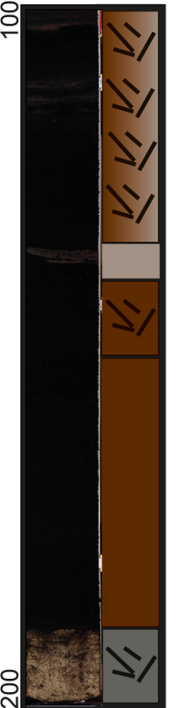

(b) Max Gundelach

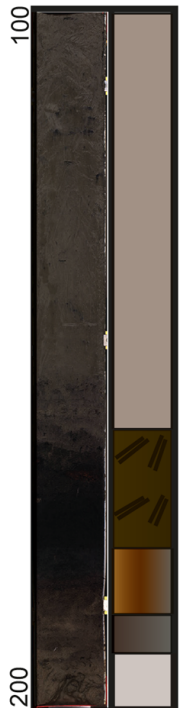

(c) Theodor

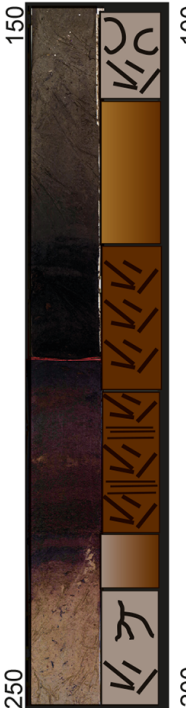

(d) Westland

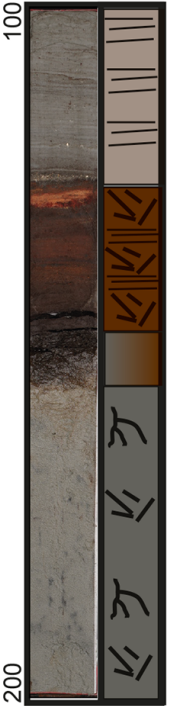

(e) Dorthea Shallow SW

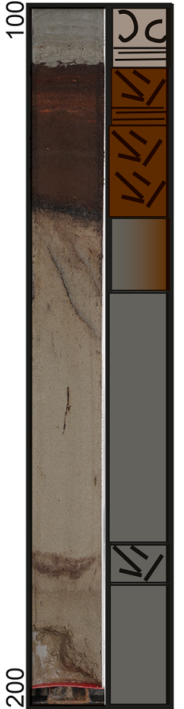

(f) Dorthea SSW
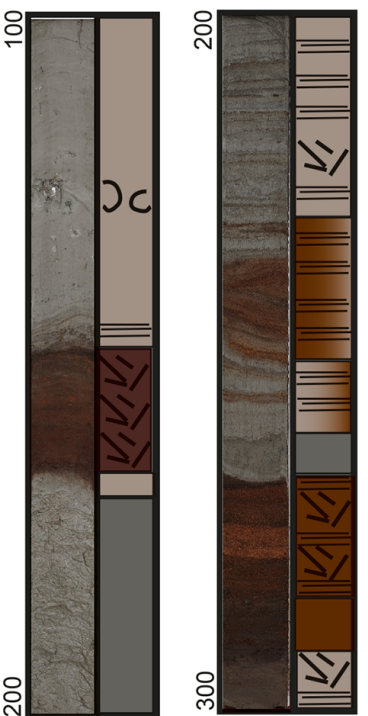

(g) Dorthea NW (h) Fredricksborg NE

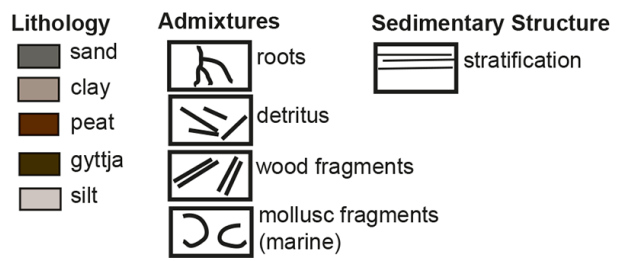

Figure 2. Photographs and stratigraphy of key sites. (a-d) The four sites from which sediments were used to perform 16S rRNA gene-based diversity analysis. These sites lie within the middle and southern North Sea. (e-f) The four sites from which sediment was used to study microbial activity. These sites originate from the Dogger Bank area. Note the varying $y$ axes.

Table 1. Radiocarbon dates. The ${ }^{14} \mathrm{C}$ dates of the Max Gundelach site in the Vlieland area and the Fredricksborg NE site in the Dogger Bank area, the two sites where plant macrofossil analysis was performed.

\begin{tabular}{lrllrr}
\hline Site & d.b.s.f. $(\mathrm{cm})$ & Lab ID & Dated material & ${ }^{14}$ C age BP & $\begin{array}{r}\text { Calibrated age BP } \\
\text { (95 \% min and max range) }\end{array}$ \\
\hline Max Gundelach & $104-106$ & GrM-17947 & Charcoal & $7475 \pm 35$ & $8290(8190-8380)$ \\
Max Gundelach & $106-108$ & GrM-17751 & Cladium mariscus & $7540 \pm 35$ & $8360(8220-8420)$ \\
Max Gundelach & $123-125$ & GrM-18853 & $\begin{array}{l}\text { Carex spp. } \\
\text { Betula pubescens/pendula }\end{array}$ & $7890 \pm 40$ & $8720(8590-8980)$ \\
Max Gundelach & $188-190$ & GrM-17752 & Carex sp., Typha sp. & $10120 \pm 35$ & $11760(11500-12010)$ \\
\hline Fredricksborg NE & $265-267$ & GrM-19239 & Cyperaceae & $11020 \pm 40$ & $12880(12740-13010)$ \\
Fredricksborg NE & $289-291$ & GrM-19287 & Carex section Acutae & $11885 \pm 40$ & $13680(13570-13780)$ \\
\hline
\end{tabular}

2004). Peat formation by paludification began at $183 \mathrm{~cm}$ depth, evidenced by a sudden increase (to $75 \%$ ) in OM when incinerated at $550^{\circ} \mathrm{C}$.

The plant macrofossil content of the peat deposits in Fredricksborg NE (Fig. 4b) is dominated by bryophytes, Sphagnum, and brown mosses. Peat accumulation began with Sphagnum papillosum, quickly followed by the brown moss Tomentypnum nitens and subsequently by the brown mosses Warnstorfia sp. and Drepanocladus sp. Sphagnum papillosum is a typical moss of an acidic raised bog, but in the
Netherlands it also occurs in fenland areas, as well as sand regions, including dune slacks, e.g. on the Wadden Islands (Bryologische en Lichenologische Werkgroep, 2015).

\subsection{Estimating $\mathrm{CH}_{4}$ storage, $\mathrm{OM}$, and $\mathrm{CO}_{2}$ equivalents}

The study area $(116 \mathrm{~km}$ by $372 \mathrm{~km}$; Fig $1 \mathrm{~b})$ spans a surface area of $43158 \mathrm{~km}^{2}$, an area larger than the land surface of the Netherlands $\left(41865 \mathrm{~km}^{2}\right)$. Based on the average peat thickness of $0.29 \mathrm{~m}$ (min: $0.07 \mathrm{~m}$; $\max : 0.88 \mathrm{~m}$ ), the estimated vol- 

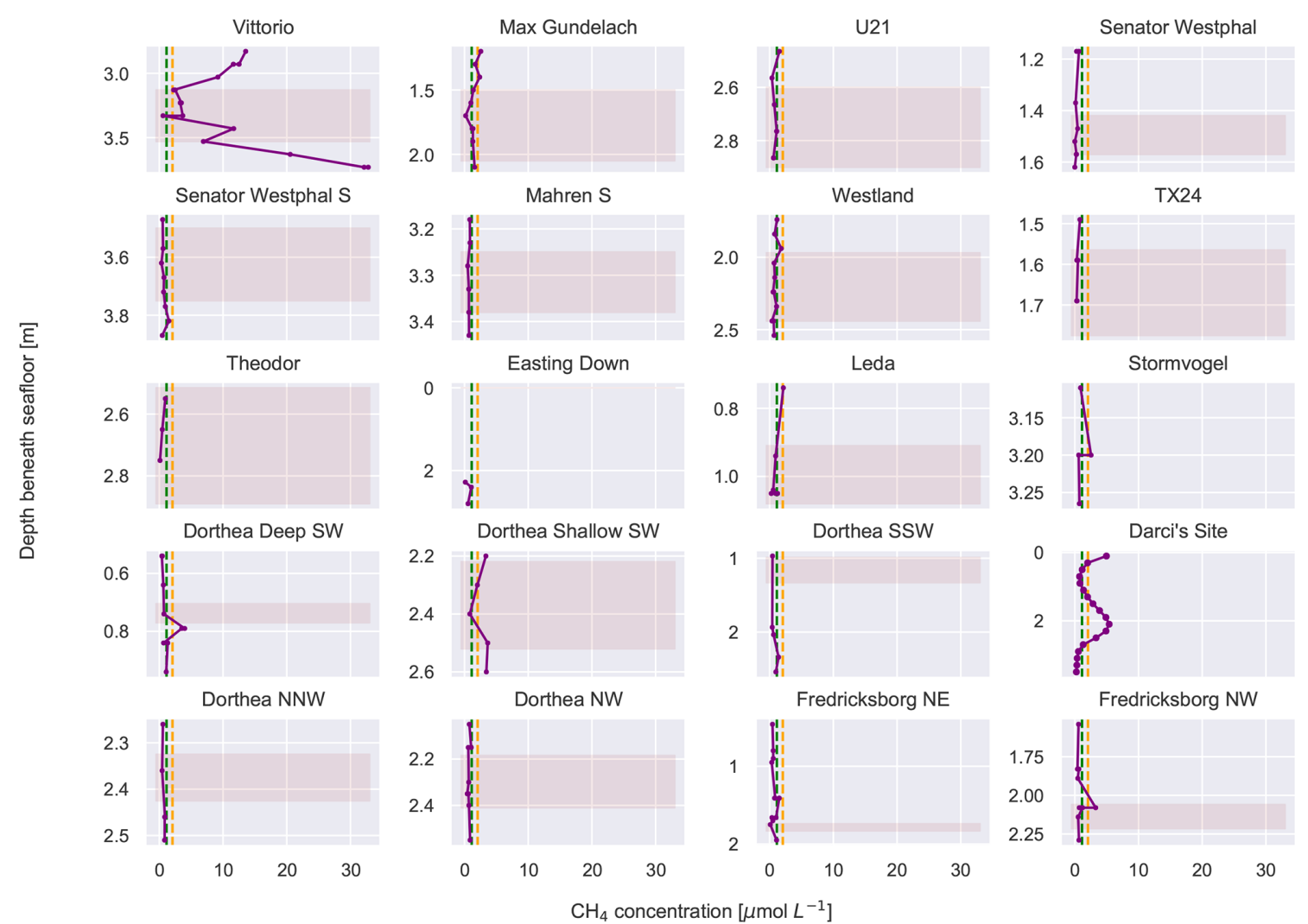

Figure 3. Depth profiles of methane concentrations at all sites (in $\mu \mathrm{mol} \mathrm{L}^{-1}$ ). The yellow line indicates the average methane concentration across all measurements. The green line indicates the average methane concentrations of seawater measured in the same area (Borges et al., 2016). The pink shaded regions are indicative of peat. Note the varying $y$ axes.

ume of peat is $12.4 \mathrm{~km}^{3}$ (min: 3.0 ; $\max : 38.0 \mathrm{~km}^{3}$ ). Multiplying this estimated volume by the average observed $\mathrm{CH}_{4}$ concentration $\left(2.14 \mu \mathrm{mol} \mathrm{L}^{-1}\right)$, we estimate that $0.411 \mathrm{Tg} \mathrm{CH}_{4}$ (min: 0.100; max: $1.256 \mathrm{Tg} \mathrm{CH}_{4}$ ) is present in the study area.

Carbon storage and its $\mathrm{CO}_{2}$ equivalent were calculated using the estimated peat volume of $12.4 \mathrm{~km}^{3}$ and $103 \mathrm{~kg} \mathrm{~m}^{-3}$, the average OM density of compressed peat in the Netherlands (Erkens et al., 2016). This volume of peat is estimated to hold $740.8 \mathrm{Tg} \mathrm{C}$ (min: 180.4; max: 2270.1), assuming the convention that dry peat biomass has a carbon concentration of $0.5 \mathrm{~g} \mathrm{C} \mathrm{g}^{-1}$ (Gorham, 1991; Heijmans et al., 2008). This is equivalent to $2716.2 \mathrm{Tg} \mathrm{CO}_{2}$ (min: 661.5; $\max : 8323.8$ ), if released into the atmosphere, assuming a conversion of soil $\mathrm{C}$ to $\mathrm{CO}_{2}$ of $1.00: 3.67$ (Van den Bos, 2003).

\subsection{Variations in OM between local environments}

Scatter plots show the LOI when incinerated at 330 and $550^{\circ} \mathrm{C}$ with depth (Fig. S2). OM loss at 330 and $550^{\circ} \mathrm{C}$ follow comparable trends at all sites. There was a general ceiling of not more than $50 \%$ loss at LOI $330^{\circ} \mathrm{C}$. OM loss at $330^{\circ} \mathrm{C}$ was highest at the Vittorio (core 6.2) and Fredricksborg NE (core 111.0) sites. Large (80\%) OM loss when incinerated at $550^{\circ} \mathrm{C}$ was observed at all sites, except at the
Theodor site. The thickness of the peat layer at the Theodor site was $8 \mathrm{~cm}$, thinner than the mean peat layer thickness $(0.29 \mathrm{~m})$. The Fredricksborg NE site was distinct from the other sites because the difference in LOI when incinerated at 330 and $550^{\circ} \mathrm{C}$ was small, indicating that a higher portion of material was incinerated at a lower temperature.

\subsection{Methanogenic archaea actively perform methylotrophic methanogenesis}

To investigate the potential of the in situ microbial community for $\mathrm{CH}_{4}$ cycling (schematic of process, Fig. 1a), batch incubations were prepared with an anoxic slurry of artificial seawater and freshly collected peat sediment and amended with a range of methanogenic substrates. Pore water analysis indicated that the peat layers were converted into a marine ecosystem (Table S2). The peat deposits at Dorthea Shallow SW, Dorthea SSW, Dorthea NW, and Fredricksborg NE showed active $\mathrm{CH}_{4}$ production upon incubation, with a strong increase in rates of production upon methylated substrate amendment (Fig. 5). Molecular analysis showed that methanogens were present at all four assessed sites: Westland, Senator Westphal, Max Gundelach, and Vittorio (Fig. 6). 


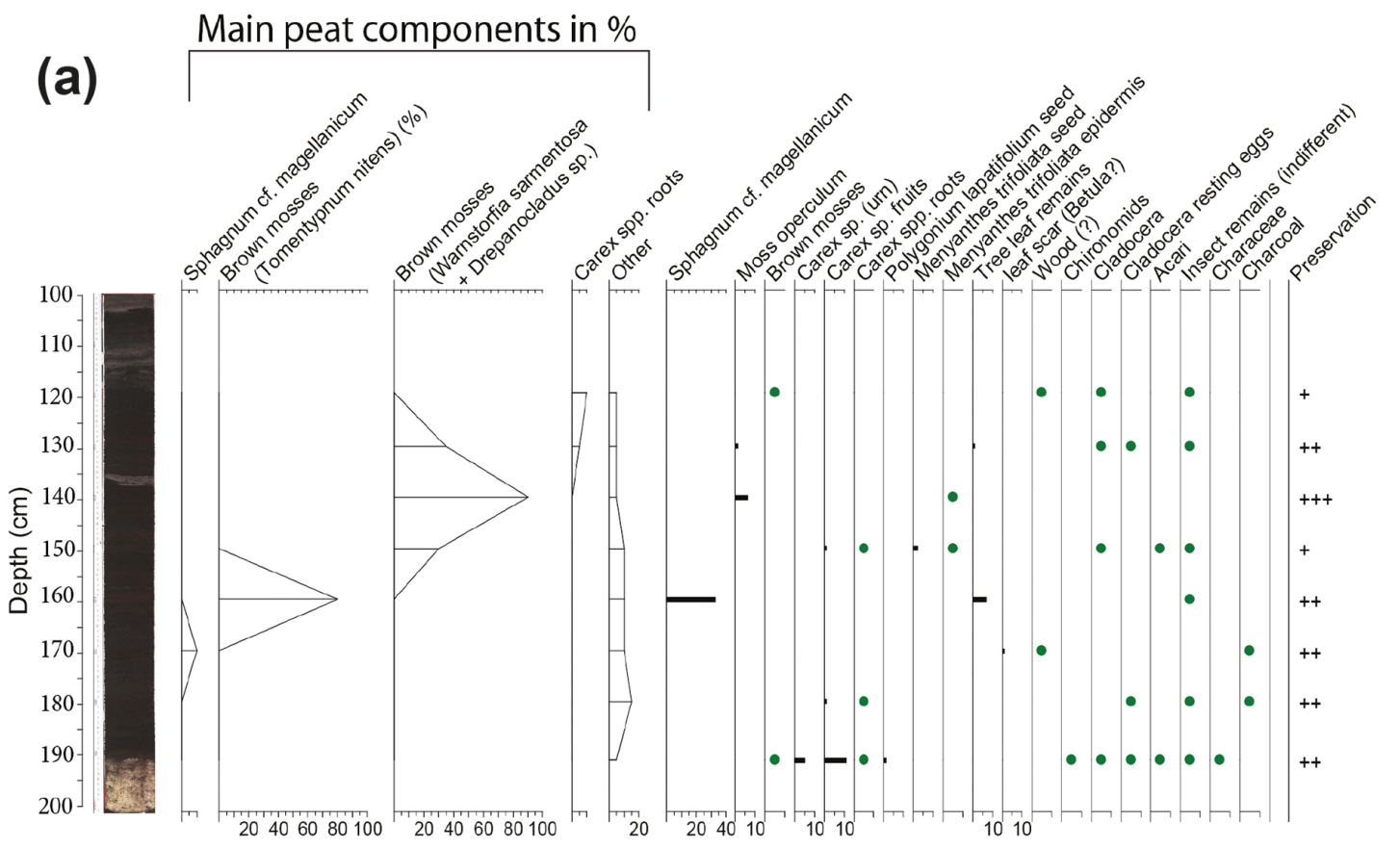

(b)

Main peat components in \%

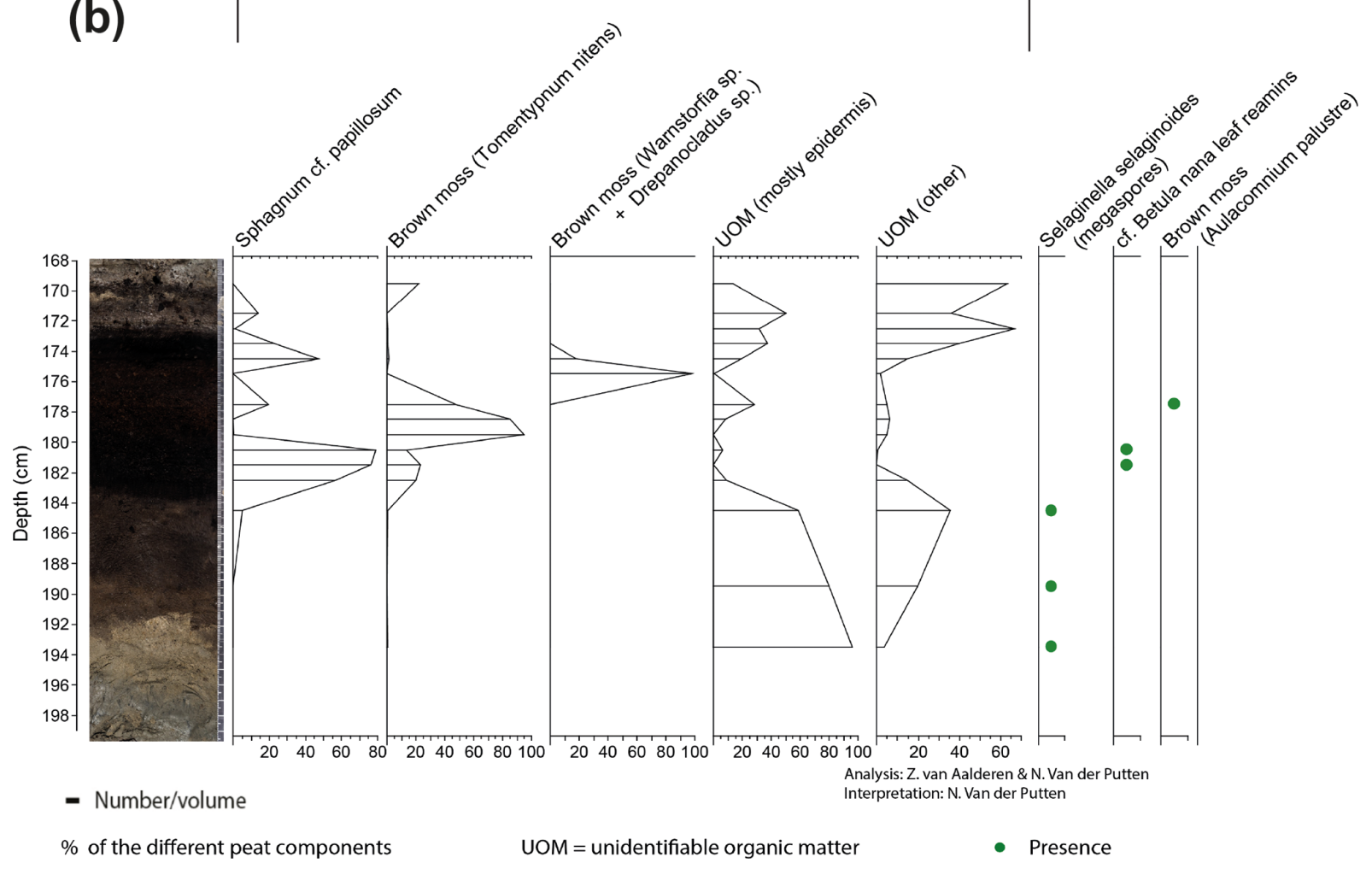

Figure 4. Macrofossil diagrams of the (a) Max Gundelach site. Preservation of the plant remains are qualitatively estimated and expressed using a three-step scale: + (good), ++ (very good), and +++ (excellent). (b) The Fredricksborg NE site against depth and core photograph The main peat components of both sites are quantified using the quadrat and leaf count (QLC) method (see methods). They are expressed as percentages $(\%)$ and are shown as hollow curves, with the lines indicating the depth of the samples. The complete sample was screened for additional less abundant taxa which are expressed as concentrations (number of remains per unit of volume) and shown as black bars. Rare taxa are shown as being present with green dots. 
Methane production in the unamended control incubation was very low, indicating that most, if not all, of the labile OM fraction of the peat sediments has already been mineralized. Methane accumulation was observed subsequent to the addition of methylated substrates (Fig. 5) after a lag phase of 2 weeks, indicating that the $\mathrm{CH}_{4}$-producing microbial community could be quickly metabolically revived. In the incubation with $\mathrm{H}_{2}$ and $\mathrm{MeOH}, \mathrm{CH}_{4}$ production was solely linked to $\mathrm{MeOH}$, which was confirmed upon amendment with $\mathrm{MeOH}$ after depletion of $\mathrm{H}_{2}$.

Amendment with hydrogen and $\mathrm{CO}_{2}\left(\mathrm{H}_{2} / \mathrm{CO}_{2}\right)$ and acetate, two common substrates for methanogenic archaea, did not induce $\mathrm{CH}_{4}$ production within the period of incubation (60 d). Even though no methanogenesis was observed, the concentration of $\mathrm{H}_{2} / \mathrm{CO}_{2}$ changed. This may be indicative of competition for substrates, likely by sulfate-reducing microorganisms facilitated by abundant sulfate supplies that penetrate up to metres deep into the sediment in marine environments (Jørgensen, 1983) or, in this case, incubations with ample supplies of sulfate. Amendment with methoxyphenol (MPH) and trimethoxybenzoate (TMB), substrates used by methoxydotrophic methanogens, did not induce $\mathrm{CH}_{4}$ production, and a TMB concentration of $3 \mathrm{mM}$ appeared to be inhibitory to the methanogenic community. Neither aerobic nor anaerobic methanotrophic activity was observed, indicating the absence of an in situ biological $\mathrm{CH}_{4}$ filter (Figs. S3, S5).

\subsection{Microbial community composition}

$16 \mathrm{~S}$ rRNA gene quantification shows the dominance of archaea over bacteria in all cores. Archaeal and bacterial abundances in each core section were assessed by qPCR. In all cores, archaea were more abundant than bacteria (Table S3 and Fig. S4). Cores 6 and 7 had archaea-to-bacteria ratios of 7.0 and 9.0, whereas cores 17 and 26 had ratios of 55.1 and 43.9, respectively. Archaeal 16S rRNA gene copy numbers ranged from 1.3 to $8.1 \times 10^{7}$, while bacterial $16 \mathrm{~S}$ rRNA gene copy numbers ranged from 1.7 to $3.2 \times 10^{6}$.

\subsubsection{Dominance of Bathyarchaeota and prevalence of methanogenic archaea}

Bathyarchaeota dominated the archaeal communities at all locations, with an average relative abundance of $71 \%$ (range $35.9 \%-92.2 \%$ ). The relative abundance of Bathyarchaeota was highest at the Max Gundelach site, with an average of $86 \%$ of the archaeal 16S rRNA gene reads. The phylum Bathyarchaeota is a potentially metabolically diverse microbial group that is found in a wide range of organic-rich environments, including deep-sea and freshwater sediments (Evans et al., 2015). Among the four sites for which DNA sequencing was performed, methanogenic archaea were detected at Vittorio, Max Gundelach and Westland but not Senator Westphal S (Figs. 6 and S4). Methanogenic archaeal species belonging to Methanomassiliicoccaceae were detected in these three cores, whereas Methanoregulaceae were only observed at Max Gundelach. The Max Gundelach site contained the highest relative abundance of methanogenic archaea, with an average of $10.3 \%$, compared to averages of $3.9 \%$ and $3.0 \%$ at the Vittorio and Westland sites, respectively.

Lokiarchaea were most abundant at the Vittorio site $(32.2 \%)$ and were present in only low abundance at the Westland site $(2.8 \%)$ and below the $2 \%$ threshold at the other sites (Fig. 6). Marine Benthic Group D and DHVEG1 were more abundant at the Senator Westphal S and Westland sites (30.3\% and $21.2 \%$, respectively) and were present only in low abundance at the Vittorio and Max Gundelach sites (1.4\% and $2.7 \%$, respectively). Genomic analysis of the Asgard candidate phylum "Candidatus Lokiarchaeota" has indicated the potential for an acetogenic lifestyle, hydrogen dependency, and mixotrophic potential (Sousa et al., 2016; Spang et al., 2019).

\subsubsection{Diverse bacterial communities dominated by candidate phylum JS1}

Candidate phylum JS1 dominated the bacterial communities, with an average relative abundance of $22.9 \%$ (Fig. 6). The highest relative abundances, $33.7 \%$ and $26.3 \%$, were observed at the Vittorio and Max Gundelach sites, respectively. Dehalococcoidia were mainly observed at the Vittorio and Max Gundelach sites, with respective abundances of $12.3 \%$ and $18.4 \%$. At the Senator Westphal S and Westland sites, the abundances of Dehalococcoidia were low, with averages of $1.6 \%$ and $0.8 \%$, respectively. The JS1 lineage is a subgroup of the candidate phylum Atribacteria (Nobu et al., 2016). Metabolic reconstructions have indicated the potential of JS1 bacteria for fermentative metabolism and syntrophic acetate oxidation (Lee et al., 2018). Aerophobetes and GIF9 phylum bacteria were more characteristic of the Senator Westphal S $(6.7 \%)$ and Westland $(8.1 \%)$ sites and were present only in low abundance at the Vittorio (1.6\%) and Max Gundelach $(0.8 \%)$ sites. Candidate GIF9 bacteria were only detected at the Senator Westphal S (3.4\%) and Westland $(7.2 \%)$ sites. In addition, MSB.5B2, TA06, SBR1031, Pla_1 lineage (Senator Westphal S site only), Pirellulales (Senator Westphal S site only), and Phycisphaerales (Westland site only) were unique to specific cores.

\subsubsection{Archaeal and bacterial diversity analyses}

Archaeal species diversity was greater at the Senator Westphal S (Simpson: 0.24; Shannon: 2.13) and Westland (Simpson: 0.19; Shannon: 2.85) sites than at the Vittorio (Simpson: 0.21; Shannon: 2.28) and Max Gundelach (Simpson: 0.23; Shannon: 1.96) sites (Fig. S6a). The archaeal community structure was similar among the cores, as supported by non-metric multidimensional scaling (Fig. S7). 


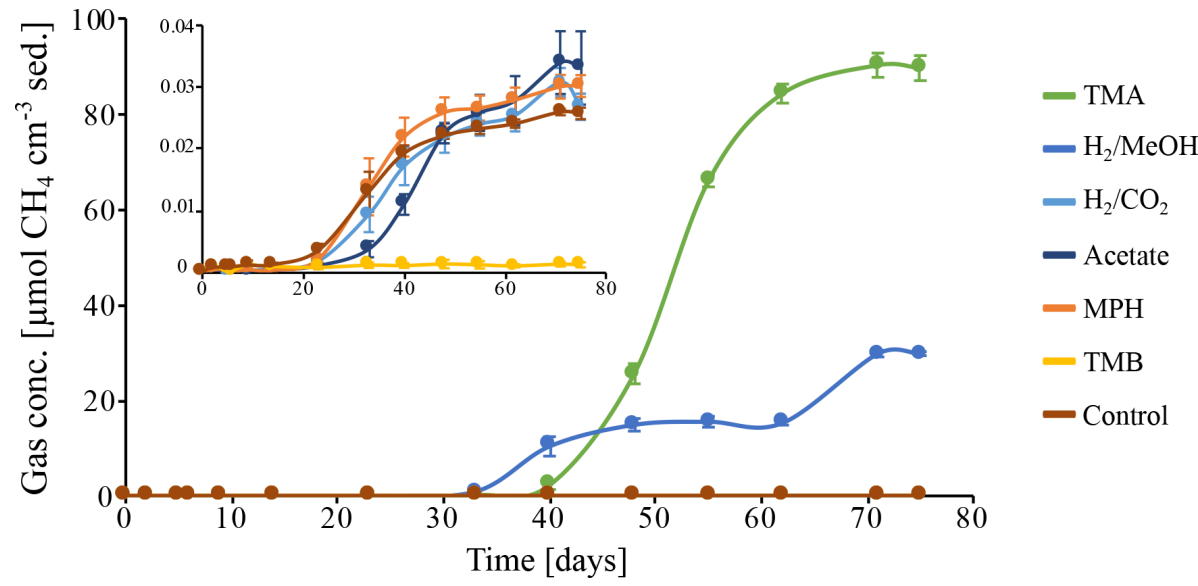

Figure 5. Methane production in batch incubations of peat sediment slurries, in which $\mathrm{CH}_{4}$ is expressed as $\mathrm{CH}_{4} \mathrm{~cm}^{-3}$ of original peat sediment over the course of $75 \mathrm{~d}$. Substrates: trimethylamine (TMA), hydrogen and methanol $\left(\mathrm{H}_{2} / \mathrm{MeOH}\right)$, hydrogen and $\mathrm{CO}_{2}\left(\mathrm{H}_{2} / \mathrm{CO}_{2}\right)$, acetate, methoxyphenol (MPH), trimethoxybenzoate (TMB), and an anaerobic control incubation without substrate amendment (Control). Data points represent the average of triplicate measurements on triplicate incubations. Error bars indicate the standard deviation of the mean. The insert depicts a zoom in on the $\mathrm{CH}_{4}$ concentrations excluding the incubations on TMA and $\mathrm{H}_{2} / \mathrm{MeOH}$.

(a)

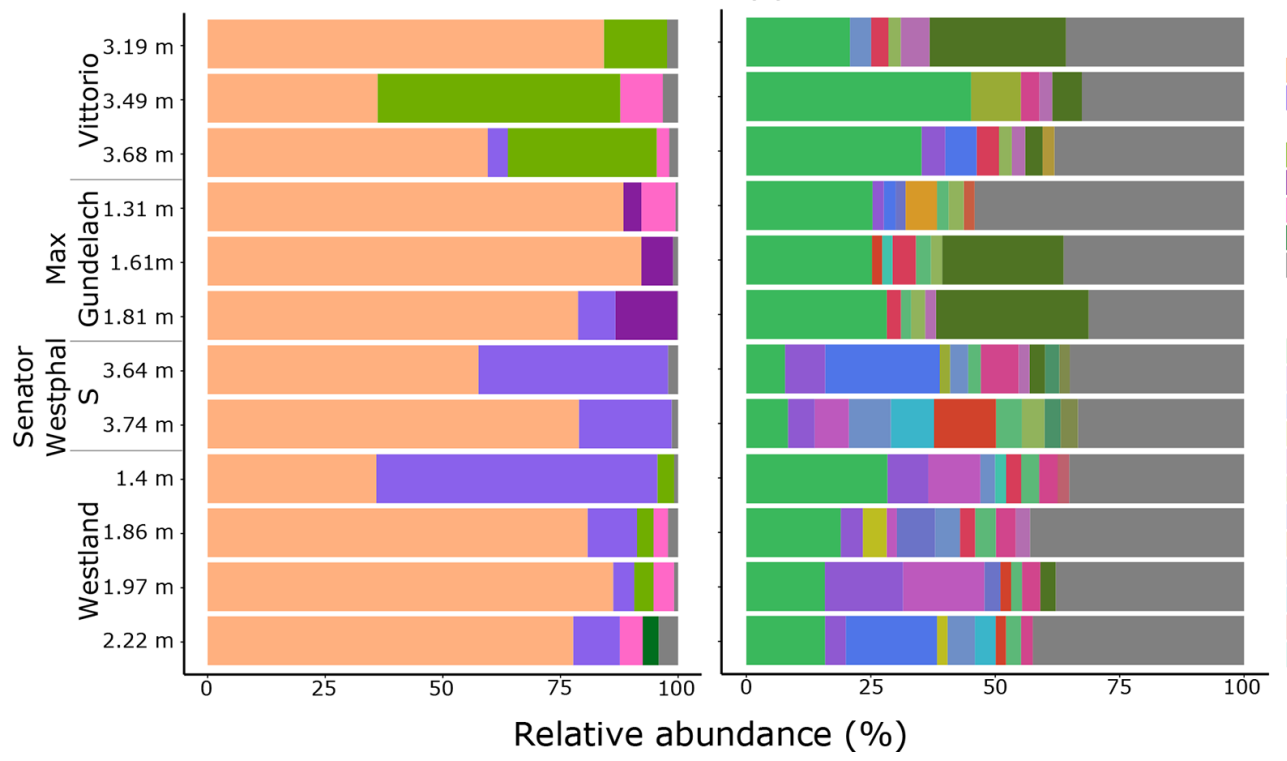

(b)

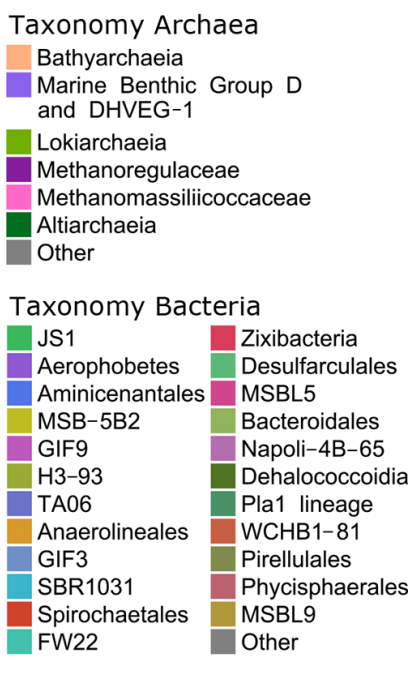

Figure 6. Phylogenetic classification of amplified archaeal (a) and bacterial (b) 16S rRNA genes. The $y$-axis values indicate the depth beneath seafloor (d.b.s.f.). The maximum taxonomy depth is on family level. Taxonomic groups with $<2 \%$ abundance are grouped in "Other".

The high microbial diversity of these peat sediments was reflected in the alpha diversity indices. Compared to inundated mangrove peat soils, the bacterial alpha diversity in the North Sea peat sediments sampled in the present study was higher (Shannon diversity of up to 5 vs. 2.81; Fig. S6b.) (Chambers et al., 2016). The indicators of diversity observed here were comparable to or higher than those observed in tropical peat swamp forests in Thailand (Shannon diversity of 5.07) and Indonesia (2.0-2.5), but the largest estimated Chao1 index was much higher (1054 for Thailand peat vs.
1500-4500 observed in our study) (Chambers et al., 2016; Kwon et al., 2016).

\section{Discussion}

These findings indicate that basal peats have the potential to function as $\mathrm{CH}_{4}$ storage facilities and may improve global inventories of marine carbon, $\mathrm{CO}_{2}$, and $\mathrm{CH}_{4}$. 


\subsection{Origins of this newly measured $\mathrm{CH}_{4}$ store}

These findings confirm the long held hypothesis that pools of $\mathrm{CH}_{4}$ are present in North Sea basal peats (Judd et al., 1997; Missiaen et al., 2002). We estimate $0.411 \mathrm{Tg} \mathrm{CH}_{4}$ remains trapped within these basal peats. Peatlands in the presentday North Sea basin developed due to rising groundwater linked to postglacial sea level rise and were rapidly capped by marine clays and sand deposits. It is likely that the rapid inundation of the peatland led to the production of large volumes of $\mathrm{CH}_{4}$ by methanogenic microbial populations. Seismic surveys of the southern North Sea have indicated that $\mathrm{CH}_{4}$-containing pockmarks are likely of biogenic origin due to a lack of observed underlying marine seeps that would be a necessary conduit of geological $\mathrm{CH}_{4}$ into shallow sediments (Missiaen et al., 2002). Whilst seismic studies in the northern North Sea hypothesized that $\mathrm{CH}_{4}$-containing shallow sand sediments are of both biogenic and geological origin due to ascending gas emission pathways through the sediment, these pathways have not been observed (Hovland and Judd, 1988; Hovland et al., 1987; Niemann et al., 2005).

We see two potential explanations for the production of biogenic in situ $\mathrm{CH}_{4}$ in these basal peats. Firstly, this $\mathrm{CH}_{4}$ may have been produced during the postglacial flooding of active peatlands in the region that is now the North Sea basin, and without sufficient methanotrophic metabolization, remains were trapped by overlying sediment in basal peat deposits. Alternatively, the $\mathrm{CH}_{4}$ may have been produced in the present day, with the activity of methanogens exceeding the activity of methanotrophs.

Whilst the incubations show that methanogenic populations were revived within a 2 week window, methanogens were not observed to be active in the present day (Fig. 5). Further, microbial-activity-based analyses show that neither aerobic nor anaerobic methanotrophic prokaryotes were activated by oxic or anoxic incubations. Therefore, we did not observe processes indicating biogenic $\mathrm{CH}_{4}$ may have been produced in the present day.

Whilst the processes of diffusion, ebullition, and methanotroph metabolization of $\mathrm{CH}_{4}$ are likely to have occurred during the postglacial flooding of peatlands, pools of $\mathrm{CH}_{4}$ may remain if inhibited by a sufficiently dense, sufficiently rapidly deposited overlying sediment layer. The overlying sediment layers may be sufficiently dense to inhibit upward gas diffusion and ebullition. It is likely that the compacted nature of basal peats impacts the diffusion of $\mathrm{CH}_{4}$ through the sediment (Grunwald et al., 2009).

We conclude that in the observed absence of active methanogenic and methanotrophic microbial populations, the in situ $\mathrm{CH}_{4}$ observed in this study is trapped pockets of millennia-old $\mathrm{CH}_{4}$. This supports previous seismic studies not undertaken in situ that have indicated that pools of $\mathrm{CH}_{4}$ are present in the basal peats beneath the North Sea but contradicts the hypothesis that this $\mathrm{CH}_{4}$ was produced in the present day (Missiaen et al., 2002). Future studies may consider isotopic analysis to confirm the origin.

\subsection{In the context of the global $\mathrm{CH}_{4}$ budget}

Due to unattributable changes in atmospheric $\mathrm{CH}_{4}$ concentrations in the last decade, quantification of the global $\mathrm{CH}_{4}$ budget has been a focal point of discussion in the literature. In these quantification efforts, wetland emissions provided the largest source of uncertainty (Saunois et al., 2020). Methane present in basal peats went unaccounted for and is therefore underrepresented in these $\mathrm{CH}_{4}$ accounting efforts.

For comparison with global $\mathrm{CH}_{4}$ inventories, the estimated $0.411 \mathrm{Tg} \mathrm{CH}_{4}$ present in these submerged sediments is equivalent to almost one quarter of the annual biogenic oceanic $\mathrm{CH}_{4}$ emissions ( $2 \mathrm{Tg} \mathrm{CH}_{4} \mathrm{yr}^{-1}$ ) (Saunois et al., 2020), 1 month of the global growth of atmospheric $\mathrm{CH}_{4}$ that occurred during the years $2000-2009\left(5.8 \mathrm{Tg} \mathrm{yr}^{-1}\right)$, or 1.5 weeks of the global atmospheric $\mathrm{CH}_{4}$ growth that occurred in 2017 (16.8 $\mathrm{Tg} \mathrm{yr}^{-1}$ ) (Saunois et al., 2020).

The $\mathrm{CH}_{4}$ concentrations of $1-30 \mu \mathrm{mol} \mathrm{L}^{-1}$ observed in the peat layer of the middle and southern North Sea in the present study are an order of magnitude higher than background concentrations measured in shallow North Sea sediments $\left(<0.1 \mu \mathrm{mol} \mathrm{L}^{-1}\right.$; Niemann et al., 2005; Steinle et al., 2016) and much higher than concentrations observed in the water column (maximum of $1.1 \mu \mathrm{mol} \mathrm{L}^{-1}$; Borges et al., 2016), with the exception of muddy sediments like those of the Helgoland Bight, where observed $\mathrm{CH}_{4}$ concentrations reached values of up to $6 \mathrm{mmol} \mathrm{L}^{-1}$ (Aromokeye et al., 2020). Borges et al. (2016) reported average $\mathrm{CH}_{4}$ concentrations in the water column of $0.139 \mu_{\mathrm{mol} \mathrm{L}}^{-1}$ (near-shore) and $0.024 \mu \mathrm{mol} \mathrm{L}^{-1}$ (off-shore) and a maximum concentration of $1.128 \mu \mathrm{mol} \mathrm{L}^{-1}$.

Due to a lack of published research, it is not possible to compare the $\mathrm{CH}_{4}$ concentrations measured here with those of other basal peat deposits. Compared to studies that have measured $\mathrm{CH}_{4}$ concentrations in marine sediments (Egger et al., 2016, 2017; Niemann et al., 2005; Steinle et al., 2016), the geographic expanse of this study area is large. At all sites, $\mathrm{CH}_{4}$ concentrations were above previously reported background concentrations of shallow sediments and background concentrations of bottom seawater. The broad distribution of the sample locations (study area in Fig. 1a; $43158 \mathrm{~km}^{2}$ ) is indicating that this dataset has reliably captured the variability of the $\mathrm{CH}_{4}$ concentrations present in southern and midNorth-Sea basal peats. The $\mathrm{CH}_{4}$ concentrations measured in this study are higher than those measured in the water column in the same area (Zhuang et al., 2018). The Darci site is influenced by a known biogenic $\mathrm{CH}_{4}$ gas seep located $\sim 600 \mathrm{~m}$ beneath the seafloor (Schroot et al., 2005). The $\mathrm{CH}_{4}$ concentrations observed in these peat deposits are lower than but similar in magnitude to those found in a near-surface $(<0.2 \mathrm{~m}$ d.b.s.f.) highly active gas seep in the northern North Sea (Niemann et al., 2005). The highest $\mathrm{CH}_{4}$ concentrations 
were measured at the Vittorio site, the site of the second thickest peat layer. However, we did not find evidence that the thickness of the basal peat was linked to $\mathrm{CH}_{4}$ concentrations as both thick and thin peat layers harboured both high and low concentrations (Fig. 3).

\subsection{A newly measured carbon store}

The study area spans $43158 \mathrm{~km}^{2}$, approximately $10 \%$ of present-day European peatlands (Xu et al., 2018) and larger than the surface area of the Netherlands. We estimate the total carbon stored in these submerged basal peat deposits to be $741 \mathrm{Tg} \mathrm{C}$, corresponding to an average of $0.017 \mathrm{Tg} \mathrm{C} \mathrm{km}^{-2}$. The $741 \mathrm{TgC}$ stored in these submerged peats is equivalent to $70 \%$ of the $1030 \mathrm{TgC}$ stored in Dutch peatlands today (Erkens et al., 2016) or $2.4 \%$ of the $30600 \mathrm{Tg} \mathrm{C}$ stored in the globe's largest peatland $\mathrm{C}$ storage facility, the Congo Basin complex (Dargie et al., 2017). This $\mathrm{C}$ has the potential to be released into the overlying water column in the occurrence of a marine seep that could be initiated naturally or an outcome of fossil fuel extraction (Schneider von Deimling et al., 2015).

\subsection{Methanogenic but no methanotrophic communities}

Oxic and anoxic batch incubations were used to assess both the $\mathrm{CH}_{4}$ production and consumption potential of these basal peat deposits. Methanogenesis was observed on methylated compounds only. In contrast to $\mathrm{H}_{2} / \mathrm{CO}_{2}$ and acetate, methylated compounds are a non-competitive methanogenic substrate that is metabolized by Methanosarcinales (Lyimo et al., 2000). Surprisingly, observations did not indicate the presence of this methanogenic family.

No aerobic or anaerobic methanotrophic prokaryotes were found in these peat deposits. Like many marine sediments, the anoxic and marine nature of the environment likely led to the exclusion of an aerobic methanotrophic population (Conrad et al., 1995). In addition, the low $\mathrm{CH}_{4}$ partial pressure probably inhibited sulfate-dependent anaerobic oxidation of $\mathrm{CH}_{4}$ (Thauer, 2011). Sulfate reduction in these sediments is likely linked to $\mathrm{H}_{2}$ and acetate oxidation (Oremland and Polcin, 1982). Environments with methanogens but not methanotrophs are uncommon but have occasionally been identified, e.g. in coal wells and masonry (Kussmaul et al., 1998; in 't Zandt et al., 2018). The absence of methanotroph activity is congruent with their absence in the results of $16 \mathrm{~S}$ rRNA gene amplicon sequencing and confirms that methanotrophic species are most likely not present or active in this environment.

Methanotrophs have the potential to be activated in the presence of additional $\mathrm{CH}_{4}$. Such additional $\mathrm{CH}_{4}$ may occur due to emission caused by leakage from fossil fuel extraction, which has occurred in the local area previously (Schneider von Deimling et al., 2015). Upon activation, methanotrophs would have the potential to consume both the newly added and existing $\mathrm{CH}_{4}$ sources.

\subsection{Microbial communities are diverse across sites and depths}

We observed pronounced differences among the microbial populations at the four sampled locations (Vittorio, Max Gundelach, Senator Westphal S, and Westland sites). This heterogeneity of in situ microbial populations may be linked to the availability of residue minerals provided by plant species (Gastaldo et al., 2004; Stocker, 2012) in contrast to the homogenous results that would have been expected of an otherwise sedimentary marine ecosystem. We carried out a qPCR to investigate the relative abundance of bacteria and archaea in these samples. This is especially relevant for microorganisms in the $\mathrm{CH}_{4}$ cycle since all methanogenic microorganisms are found in the archaeal domain and provide an indication of the relative contribution of methanogenic archaea in these ecosystems.

The high $\mathrm{CH}_{4}$ concentrations observed at the Vittorio and Darci sites occurred in the presence of nitrate and ammonium (Table S2), minerals that are indicative of increased rates of biological mineralization (Burdige, 1991). However, the high ammonium concentrations observed at the Westland site were not linked to $\mathrm{CH}_{4}$ concentrations. Pore water analysis described a characteristic marine system (Table S2) indicating that marine microbes have been introduced into sediments that previously harboured freshwater microbial communities. This is reflected by the occurrence of Dehalococcoidia and candidate phylum JS1 bacteria, which are characteristic of marine sediments. These species showed the highest abundances in the two sites located nearest to each other in the study area, Vittorio and Max Gundelach SW (Nobu et al., 2016; Wasmund et al., 2014). Candidate phylum JS1 bacteria were omnipresent, whereas Dehalococcoidia were more abundant in 3 of the 12 layers, without a clear link to depth or local conditions. Although the sampling resolution was limited, this study provides the first insights into the microbial diversity of basal peat deposits and queries the role of the carbon source for the present-day microbial community composition (Figs. 5 and S4). Future studies with higher sampling resolution may provide a better understanding of the relationship between plant and microbial species.

\subsection{Plant succession is analogous across sites}

The parallel sequences observed at the Max Gundelach site in the Vlieland region and Fredricksborg NE site in the Dogger Bank region began and ended at different times, suggesting that a comparable geomorphological context was present at both sites but during different periods. The Max Gundelach peatland was established $10120 \mathrm{cal} \mathrm{yr} \mathrm{BP}$, whereas the Fredricksborg NE peatland was established $11885 \mathrm{calyr}$ BP. It is striking that the same three-step 
bryophyte-dominated sequence of Sphagnum-Tomentypnum nitens-Warnstorfia/Drepanocladus occurs in both geographically and temporally different sites. However, in contrast to the sequence of the Max Gundelach site, where Sphagnum magellanicum is present only at the start of the sequence, Sphagnum papillosum is present throughout the peat sequence at the Fredricksborg NE site. In general, plant remains are better preserved in the layers dominated by Sphagnum spp. than in those dominated by brown mosses.

These changes are aligned with the peat growth described by Wolters et al. (2010) which prevailed for ca. 1300 years before inundation occurred. The vegetation description of Wolters et al. (2010) is primarily based on pollen analysis, representative of regional-scale changes in vegetation composition. Active peat formation is dependent on the ability of peat to "keep up" with the rising groundwater table, but it is also susceptible to local topography. The differences in the duration and rate of peat accumulation are likely the result of the differences in the rate of sea level rise between these two locations, in addition to other, largely unknown palaeoenvironmental factors.

\subsection{Dominance of Bathyarchaeota suggests a role in OM turnover}

Bathyarchaeota dominated the archaeal communities of the peat sediments, with an average relative abundance of $70 \%$. This phylum is an evolutionarily diverse microbial group that is found in a wide range of organic-rich environments, including deep-sea and freshwater sediments (Evans et al., 2015). Bathyarchaeota often dominate marine subsurface archaeal communities, with relative abundances ranging from $10 \%$ to $100 \%$ (Fry et al., 2008; Zhou et al., 2018). Peatlands are rich in cellulose and lignin (McMorrow et al., 2004), which are eventually converted to fluvic and humic acids that are more accessible to the microbial community (Bozkurt et al., 2001). The growth of Bathyarchaeota subgroup 8 (Bathy8 ) on lignin suggests a key role of these species in the degradation of peat OM (Yu et al., 2018), and based on chemical rate estimation, they have been identified as one of the most active phyla in deep-sea sediments (Fry et al., 2008). These findings support the high relative abundance observed in our study and the potential role played by Bathyarchaeota in the degradation of peatland biochemicals. However, further experimental evidence is needed to confirm the role of Bathyarchaeota.

\subsection{Lokiarchaea may play an important role in microbial fermentation}

Lokiarchaeal sequences were highly abundant in the three samples of Vittorio, and this location also showed the highest $\mathrm{CH}_{4}$ accumulation values (Figs. 6 and S4). Genomebased studies have indicated that their cellular machinery includes eukaryotic signature proteins, a cytoskeleton, and phagocytic potential, suggesting Lokiarchaea are "missing link" microorganisms between prokaryotes and eukaryotes (Spang et al., 2015). Lokiarchaea have not been previously detected in peat sediments, but a previous 16S rRNA geneand metagenome-based study of sub-seafloor sediments of the Costa Rica Margin also found Lokiarchaeota among the major microbial phyla; thus, Lokiarchaeota may be indicative of a marine environment (Martino et al., 2019). Genomic analyses of "Candidatus Lokiarchaeota" have indicated an acetogenic lifestyle, hydrogen dependency, and mixotrophic potential (Sousa et al., 2016; Spang et al., 2019). Similarly, metabolic activity analyses of Namibian shelf sediments have revealed potential for homoacetogenesis (Orsi et al., 2020). Populations of Lokiarchaea may provide metabolic functions in $\mathrm{OM}$ degradation and methanogenic microbial guilds in marine sediments.

\subsection{Candidate JS1 phylum bacteria dominate the potentially heterotrophic bacterial community}

The JS1 lineage is a subgroup of the candidate phylum Atribacteria (Nobu et al., 2016). Metabolic reconstructions indicate their potential for fermentative metabolism and syntrophic acetate oxidation (Lee et al., 2018), and several studies have indicated they are abundant within marine sediments (Fry et al., 2008; Lee et al., 2018). Studies in the Skagerrak, the German Wadden Sea, and the Benguela Upwelling System showed that the upper sediment layers were mainly dominated by Delta- and Gammaproteobacteria, whereas deeper parts of the sub-seafloor were dominated by the JS1 lineage and Chloroflexi (Parkes et al., 2007; Wilms et al., 2006). This distribution is in line with our findings of high relative abundances of JS1 lineage bacteria in the peat deposits (Fig. 6). A 16S rRNA PCR-DGGE study of two Wadden Sea tidal flats (Neuharlingersieler Nacken and Gröninger Plate) found that JS1 lineage bacteria were most abundant in the Neuharlingersieler Nacken samples with the highest total organic carbon contents (1\%-2\%) (Webster et al., 2007). Considering these previous findings of JS1 lineage bacteria in organic-rich environments, it is not unexpected that JS1 are dominant bacteria in these organic rich peat deposits.

\subsection{Basal peats and associated microbiological communities are highly diverse}

Here we summarize our responses to the original hypotheses. Firstly, low $\mathrm{CH}_{4}$ concentrations were widespread across the study region with local high concentrations. Secondly, we did not find methanogens to be actively producing $\mathrm{CH}_{4}$ in the present day. Thirdly, parallel plant macrofossil sequences indicated comparable ecosystems developed across sites earmarked by paludification and inundation. This occurred at differing times, according to the influence of sea level rise on ground water. We did not observe similar patterns in microorganism populations. It is likely that the sample size of 
this study was too small to identify a relationship between the highly heterogeneous peat-forming vegetation and microbial populations. Our results suggest, but do not prove, North Sea basal peats harbour trapped pockets of millennia-old $\mathrm{CH}_{4}$. We hope that this provides an ecosystem overview and that this work can be used to design future interdisciplinary research questions to identify processes linking these different components.

\section{Conclusions}

Methane concentrations were generally low with localized exceptions. North Sea basal peat deposits function as a storage bank of observed $\mathrm{CH}_{4}$ that, in the event of physical disturbance, may be at risk of being released into the atmosphere. Microbial community structure analysis using $16 \mathrm{~S}$ rRNA gene-based sequencing techniques and incubations indicated the absence of a $\mathrm{CH}_{4}$ biofilter. Large $\mathrm{C}$ stores in the presence of methanogens and in the absence of methanotrophs have the potential to be metabolized into $\mathrm{CH}_{4}$. Whilst the source of $\mathrm{CH}_{4}$ remains unconfirmed, we conclude that in the observed absence of active methanogenic and methanotrophic microbial populations, the in situ $\mathrm{CH}_{4}$ observed in this study are most likely trapped pockets of millennia-old $\mathrm{CH}_{4}$.

Data availability. All data needed to evaluate the conclusions in the paper are present in the paper itself and/or the Supplement. Additional data related to this paper may be requested from the authors. Amplicon sequencing data were deposited in the GenBank database under the BioProject PRJNA639452 and can be accessed with SRA identifiers SRR12014238 - SRR12014261.

Supplement. The supplement related to this article is available online at: https://doi.org/10.5194/bg-18-5491-2021-supplement.

Author contributions. TJRL, MHitZ, and HAJD designed the project. TJRL, FSB, MPH, and TdG collected the data. TJRL, MHitZ, NNLvdP, PvdV, ZvA, TdG, MPH, and FSB analysed the data with assistance from OHM and CPS. TJRL, MHitZ, CUW, and HAJD prepared the manuscript with contributions from NNLvdP, MSMJ, and HN.

Competing interests. The authors declare that they have no conflict of interest.

Disclaimer. Publisher's note: Copernicus Publications remains neutral with regard to jurisdictional claims in published maps and institutional affiliations.
Acknowledgements. We thank Theo van Alen, Sihle Patience Ginindza, Cornelis Kasse, and Dave van Wees for technical assistance. We thank the Royal Netherlands Institute for Sea Research (NIOZ) and particularly Gert-Jan Reichhart, who was instrumental in organizing the two cruises. We thank the captain and the entire crew of the R/V Pelagia for enabling the success of the two sampling campaigns.

Financial support. This research has been supported by the Nederlandse Organisatie voor Wetenschappelijk Onderzoek (grant nos. 024.002.002 and 024.002.001) and the European Research Council, H2020 European Research Council (grant nos. AG Ecomom 339880 and SyG Marix 854088).

Review statement. This paper was edited by Aninda Mazumdar and reviewed by Rhiannon Mondav and one anonymous referee.

\section{References}

Aromokeye, D. A., Kulkarni, A. C., Elvert, M., Wegener, G., Henkel, S., Coffinet, S., Eickhorst, T., Oni, O. E., RichterHeitmann, T., Schnakenberg, A., Taubner, H., Wunder, L., Yin, X., Zhu, Q., Hinrichs, K. U., Kasten, S., and Friedrich, M. W.: Rates and Microbial Players of Iron-Driven Anaerobic Oxidation of Methane in Methanic Marine Sediments, Front. Microbiol., 10, 1-19, https://doi.org/10.3389/fmicb.2019.03041, 2020.

Banat, I. M., Nedwell, D. B., and Talaat Balba, M.: Stimulation of methanogenesis by slurries of saltmarsh sediment after the addition of molybdate to inhibit sulphate-reducing bacteria, J. Gen. Microbiol., 129, 123-129, https://doi.org/10.1099/00221287129-1-123, 1983.

Barber, K. E., Chambers, F. M., Maddy, D., Stoneman, R., and Brew, J. S.: A sensitive high-resolution record of late Holocene climatic change from a raised bog in northern England, The Holocene, 4, 198-205, 1994.

Barber, K. E., Chambers, F. M., and Maddy, D.: Holocene palaeoclimates from peat stratigraphy: macrofossil proxy climate records from three oceanic raised bogs in England and Ireland, Quaternary Sci. Rev., 22, 521-539, https://doi.org/10.1016/S02773791(02)00185-3, 2003.

Bjune, A. E., Birks, H. J. B., and Seppä, H.: Holocene vegetation and climate history on a continental-oceanic transect in northern Fennoscandia based on pollen and plant macrofossils, Boreas, 33, 211-223, 2004.

Bohncke, S. J. P., Van Haaster, H., and Wiegers, J.: Paludella squarrosa (Hedw.) Brid. in a late subboreal Holland peat sequence, J. Bryol., 13, 219-226, 1984.

Borges, A. V., Champenois, W., Gypens, N., Delille, B., and Harlay, J.: Massive marine methane emissions from near-shore shallow coastal areas, Sci. Rep., 6, 27908, https://doi.org/10.1038/srep27908, 2016.

Bosch, J. H. A.: Standaard boor beschrijvingsmethode, Utrecht, 2000.

Bozkurt, S., Lucisano, M., Moreno, L., and Neretnieks, I.: Peat as a potential analogue for the long-term evolution in land- 
fills, Earth Sci. Rev., 53, 95-147, https://doi.org/10.1016/S00128252(00)00036-2, 2001.

Bronk Ramsey, C.: Bayesian analysis of radiocarbon dates, Radiocarbon, 51, 337-360, 2009.

Bryologische en Lichenologische Werkgroep, N.: NDFF Verspreidingsatlas, available at: http://www.verspreidingsatlas.nl/mossen (last access: 14 September 2020), 2015.

Burdige, D. J.: The kinetics of organic matter mineralization in anoxic marine sediments, J. Mar. Res., 49, 727-761, https://doi.org/10.1357/002224091784995710, 1991.

Cadillo-Quiroz, H., Bräuer, S., Yashiro, E., Sun, C., Yavitt, J., and Zinder, S.: Vertical profiles of methanogenesis and methanogens in two contrasting acidic peatlands in central New York State, USA, Environ. Microbiol., 8, 1428-1440, https://doi.org/10.1111/j.1462-2920.2006.01036.x, 2006.

Caporaso, J. G., Lauber, C. L., Walters, W. A., Berg-Lyons, D., Huntley, J., Fierer, N., Owens, S. M., Betley, J., Fraser, L., Bauer, M., Gormley, N., Gilbert, J. A., Smith, G., and Knight, R.: Ultra-high-throughput microbial community analysis on the Illumina HiSeq and MiSeq platforms, ISME J., 6, 1621-1624, https://doi.org/10.1038/ismej.2012.8, 2012.

Carr, S. A., Schubotz, F., Dunbar, R. B., Mills, C. T., Dias, R., Summons, R. E., and Mandernack, K. W.: Acetoclastic Methanosaeta are dominant methanogens in organicrich Antarctic marine sediments, ISME J., 12, 330-342, https://doi.org/10.1038/ismej.2017.150, 2018.

Chambers, L. G., Guevara, R., Boyer, J. N., Troxler, T. G., and Davis, S. E.: Effects of Salinity and Inundation on Microbial Community Structure and Function in a Mangrove Peat Soil, Wetlands, 36, 361-371, https://doi.org/10.1007/s13157016-0745-8, 2016.

Charman, D. J., Beilman, D. W., Blaauw, M., Booth, R. K., Brewer, S., Chambers, F. M., Christen, J. A., Gallego-Sala, A., Harrison, S. P., Hughes, P. D. M., Jackson, S. T., Korhola, A., Mauquoy, D., Mitchell, F. J. G., Prentice, I. C., Van Der Linden, M., De Vleeschouwer, F., Yu, Z. C., Alm, J., Bauer, I. E., Corish, Y. M. C., Garneau, M., Hohl, V., Huang, Y., Karofeld, E., Le Roux, G., Loisel, J., Moschen, R., Nichols, J. E., Nieminen, T. M., MacDonald, G. M., Phadtare, N. R., Rausch, N., Sillasoo, U., Swindles, G. T., Tuittila, E. S., Ukonmaanaho, L., Väliranta, M., Van Bellen, S., Van Geel, B., Vitt, D. H., and Zhao, Y.: Climate-related changes in peatland carbon accumulation during the last millennium, Biogeosciences, 10, 929-944, https://doi.org/10.5194/bg-10-929-2013, 2013.

Clymo, R. S., Turunen, J., and Tolonen, K.: Carbon Accumulation in Peatland, Oikos, 81, 368-388, https://doi.org/10.2307/3547057, 1998.

Conrad, R., Frenzel, P., and Cohen, Y.: Methane emission from hypersaline microbial mats: Lack of aerobic methane oxidation activity, FEMS Microbiol. Ecol., 16, 297-305, https://doi.org/10.1111/j.1574-6941.1995.tb00294.x, 1995.

Dargie, G. C., Lewis, S. L., Lawson, I. T., Mitchard, E. T. A., Page, S. E., Bocko, Y. E., and Ifo, S. A.: Age, extent and carbon storage of the central Congo Basin peatland complex, Nature, 542, 8690, https://doi.org/10.1038/nature21048, 2017.

Dean, J. F., Middelburg, J. J., Röckmann, T., Aerts, R., Blauw, L. G., Egger, M., Jetten, M. S. M., de Jong, A. E. E., Meisel, O. H., Rasigraf, O., Slomp, C. P., in't Zandt, M. H., and Dolman, A. J.: Methane Feedbacks to the Global Cli- mate System in a Warmer World, Rev. Geophys., 56, 207-250, https://doi.org/10.1002/2017RG000559, 2018.

de Jong, A. E. E., in 't Zandt, M. H., Meisel, O. H., Jetten, M. S. M., Dean, J. F., Rasigraf, O., and Welte, C. U.: Increases in temperature and nutrient availability positively affect methane-cycling microorganisms in Arctic thermokarst lake sediments, Environ. Microbiol., 20, 4314-4327, https://doi.org/10.1111/14622920.14345, 2018.

Dickson, A. G. and Goyet, C.: Handbook of methods for the analysis of the various parameters of the carbon dioxide system in sea water, Version 2, Oak Ridge, TN, TN, 1994.

Edgar, R. C., Haas, B. J., Clemente, J. C., Quince, C., and Knight, R.: UCHIME improves sensitivity and speed of chimera detection, Bioinformatics, 27, 2194-2200, https://doi.org/10.1093/bioinformatics/btr381, 2011.

Egger, M., Rasigraf, O., Sapart, C. J., Jilbert, T., Jetten, M. S. M., Röckmann, T., Van Der Veen, C., Bânda, N., Kartal, B., Ettwig, K. F., and Slomp, C. P.: Iron-mediated anaerobic oxidation of methane in brackish coastal sediments, Environ. Sci. Technol., 49, 277-283, https://doi.org/10.1021/es503663z, 2015.

Egger, M., Kraal, P., Jilbert, T., Sulu-Gambari, F., Sapart, C. J., Röckmann, T., and Slomp, C. P.: Anaerobic oxidation of methane alters sediment records of sulfur, iron and phosphorus in the Black Sea, Biogeosciences, 13, 5333-5355, https://doi.org/10.5194/bg-13-5333-2016, 2016.

Egger, M., Hagens, M., Sapart, C. J., Dijkstra, N., van Helmond, N. A. G. M., Mogollón, J. M., Risgaard-Petersen, N., van der Veen, C., Kasten, S., Riedinger, N., Böttcher, M. E., Röckmann, T., Jørgensen, B. B., and Slomp, C. P.: Iron oxide reduction in methanerich deep Baltic Sea sediments, Geochim. Cosmochim. Ac., 207 256-276, https://doi.org/10.1016/j.gca.2017.03.019, 2017.

EMODnet: Emodnet Bathymetry, available at: https://www. emodnet.eu/ (last access: 26 August 2020), 2018.

Erkens, G., van der Meulen, M. J., and Middelkoop, H.: Double trouble: subsidence and $\mathrm{CO}_{2}$ respiration due to 1,000 years of Dutch coastal peatlands cultivation, Hydrogeol. J., 24, 551-568, https://doi.org/10.1007/s10040-016-1380-4, 2016.

Evans, P. N., Parks, D. H., Chadwick, G. L., Robbins, S. J., Orphan, V. J., Golding, S. D., and Tyson, G. W.: Methane metabolism in the archaeal phylum Bathyarchaeota revealed by genome-centric metagenomics, Science, 350, 434-438, https://doi.org/10.1126/science.aac7745, 2015.

Frenzell, P. and Karofeld, E.: $\mathrm{CH}_{4}$ Emission from a Hollow-Ridge Complex in a Raised Bog: The Role of $\mathrm{CH}_{4}$ Production and Oxidation, Biogeochemistry, 51, 91-112, 2000.

Frolking, S. and Roulet, N. T.: Holocene radiative forcing impact of northern peatland carbon accumulation and methane emissions, Glob. Change Biol., 13, 1079-1088, https://doi.org/10.1111/j.1365-2486.2007.01339.x, 2007.

Fry, J. C., Parkes, R. J., Cragg, B. A., Weightman, A. J., and Webster, G.: Prokaryotic biodiversity and activity in the deep subseafloor biosphere, FEMS Microbiol. Ecol., 66, 181-196, https://doi.org/10.1111/j.1574-6941.2008.00566.x, 2008.

Ganzert, L., Jurgens, G., Münster, U., and Wagner, D.: Methanogenic communities in permafrost-affected soils of the Laptev Sea coast, Siberian Arctic, characterized by $16 \mathrm{~S}$ rRNA gene fingerprints, FEMS Microbiol. Ecol., 59, 476-488, https://doi.org/10.1111/j.1574-6941.2006.00205.x, 2007. 
Gastaldo, R. A., Stevanović-Walls, I. M., Ware, W. N., and Greb, S. F.: Community heterogeneity of Early Pennsylvanian peat mires, Geology, 32, 693-696, https://doi.org/10.1130/G20515.1, 2004.

Gorham, E.: Northern Peatlands: Role in the Carbon Cycle and Probable Responses to Climatic Warming, Ecol. Appl., 1, 182195, https://doi.org/10.2307/1941811, 1991.

Grimm, E. C.: TGView Version 2.0. 2 [code], Illinois State Museum. Res. Collect. Center, Springfield, Illinois, USA, 2004.

Grunwald, M., Dellwig, O., Beck, M., Dippner, J. W., Freund, J. A., Kohlmeier, C., Schnetger, B., and Brumsack, H. J.: Methane in the southern North Sea: Sources, spatial distribution and budgets, Estuar. Coast. Shelf Sci., 81, 445-456, https://doi.org/10.1016/j.ecss.2008.11.021, 2009.

Hedenäs, L. and Kooijman, A.: Phylogeny and habitat adaptations within a monophyletic group of wetland moss genera (Amblystegiaceae), Plant Syst. Evol., 199, 33-52, https://doi.org/10.1007/BF00985916, 1996.

Heijmans, M. M. P. D., Mauquoy, D., Van Geel, B., and Berendse, F.: Long-term effects of climate change on vegetation and carbon dynamics in peat bogs, J. Veg. Sci., 19, 307-320, https://doi.org/10.3170/2008-8-18368, 2008.

Hendriks, D. M. D., Van Huissteden, J., Dolman, A. J., and Van Der Molen, M. K.: The full greenhouse gas balance of an abandoned peat meadow, 4, 411-424, 2007.

Herlemann, D. P., Labrenz, M., Jürgens, K., Bertilsson, S., Waniek, J. J., and Andersson, A. F.: Transitions in bacterial communities along the $2000 \mathrm{~km}$ salinity gradient of the Baltic Sea, ISME J., 5, 1571-9, https://doi.org/10.1038/ismej.2011.41, 2011.

Hijma, M. P. and Cohen, K. M.: Timing and magnitude of the sealevel jump preluding the $8200 \mathrm{yr}$ event, Geology, 38, 275-278, https://doi.org/10.1130/G30439.1, 2010.

Hijma, M. P. and Cohen, K. M.: Holocene sea-level database for the Rhine-Meuse Delta, The Netherlands: Implications for the pre-8.2 ka sea-level jump, Quaternary Sci. Rev., 214, 68-86, https://doi.org/10.1016/j.quascirev.2019.05.001, 2019.

Hijma, M. P., Cohen, K. M., Roebroeks, W., Westerhoff, W. E., and Busschers, F. S.: Pleistocene Rhine-Thames landscapes: Geological background for hominin occupation of the southern North Sea region, J. Quaternary Sci., 27, 17-39, https://doi.org/10.1002/jqs.1549, 2012.

Hovland, M. and Judd, A. G.: Seabed pockmarks and seepages impact on geology, biology and the marine environment, Graham \& Trotman, London, 1988.

Hovland, M., Talbot, M. R., Qvale, H., Olaussen, S., and Aasberg, L.: Methane-related carbonate cements in pockmarks of the North Sea, J. Sediment. Petrol., 57, 881-892, $\quad$ https://doi.org/10.1306/212f8c92-2b24-11d7$8648000102 \mathrm{c} 1865 \mathrm{~d}, 1987$.

in 't Zandt, M. H., Beckmann, S., Rijkers, R., Jetten, M. S. M., Manefield, M., and Welte, C. U.: Nutrient and acetate amendment leads to acetoclastic methane production and microbial community change in a non-producing Australian coal well, Microb. Biotechnol., 11, 626-638, https://doi.org/10.1111/17517915.12853, 2018.

Jørgensen, B. B.: Processes at the sediment-water interface, in: The Major Biogeochemical Cycles and Their Interactions, edited by: Bolin, B. and Cook, R. B., Wily, New York, USA, 477-509, 1983.
Judd, A., Davies, G., Wilson, J., Holmes, R., Baron, G., and Bryden, I.: Contributions to atmospheric methane by natural seepages on the UK continental shelf, Mar. Geol., 137, 165-189, 1997.

Judd, A. G., Hovland, M., Dimitrov, L. I., García Gil, S., and Jukes, V.: The geological methane budget at continental margins and its influence on climate change, Geofluids, 2, 109-126, https://doi.org/10.1046/j.1468-8123.2002.00027.x, 2002.

Kim, D. D., O'Farrell, C., Toth, C. R. A., Montoya, O., Gieg, L. M., Kwon, T. H., and Yoon, S.: Microbial community analyses of produced waters from high-temperature oil reservoirs reveal unexpected similarity between geographically distant oil reservoirs, Microb. Biotechnol., 11, 788-796, https://doi.org/10.1111/17517915.13281, 2018.

Klindworth, A., Pruesse, E., Schweer, T., Peplies, J., Quast, C., Horn, M., and Glöckner, F. O.: Evaluation of general 16S ribosomal RNA gene PCR primers for classical and next-generation sequencing-based diversity studies, Nucleic Acids Res., 41, 111, https://doi.org/10.1093/nar/gks808, 2013.

Kussmaul, M., Wilimzig, M., and Bock, E.: Methanotrophs and methanogens in masonry, Appl. Environ. Microbiol., 64, 4530 4532, https://doi.org/10.1128/aem.64.11.4530-4532.1998, 1998.

Kwon, M. J., Heimann, M., Kolle, O., Luus, K. A., Schuur, E. A. G., Zimov, N., Zimov, S. A., and Göckede, M.: Long-term drainage reduces $\mathrm{CO}_{2}$ uptake and increases $\mathrm{CO}_{2}$ emission on a Siberian floodplain due to shifts in vegetation community and soil thermal characteristics, Biogeosciences, 13, 4219-4235, https://doi.org/10.5194/bg-13-4219-2016, 2016.

Lee, Y. M., Hwang, K., Lee, J. Il, Kim, M., Hwang, C. Y., Noh, H. J., Choi, H., Lee, H. K., Chun, J., Hong, S. G., and Shin, S. C.: Genomic insight into the predominance of candidate phylum Atribacteria JS1 lineage in marine sediments, Front. Microbiol., 9, 1-14, https://doi.org/10.3389/fmicb.2018.02909, 2018.

Lyimo, T. J., Pol, A., Op Den Camp, H. J. M., Harhangi, H. R., and Vogels, G. D.: Methanosarcina semesiae sp. nov., a dimethylsulfide-utilizing methanogen from mangrove sediment, Int. J. Syst. Evol. Microbiol., 50, 171-178, https://doi.org/10.1099/00207713-50-1-171, 2000.

Martino, A., Rhodes, M. E., León-Zayas, R., Valente, I. E., Biddle, J. F., and House, C. H.: Microbial diversity in sub-seafloor sediments from the Costa Rica margin, Geosciences, 9, 218, https://doi.org/10.3390/geosciences9050218, 2019.

Mauquoy, D. and Van Geel, B.: Plant macrofossil methods and studies: Mire and Peat Macros, in: Encyclopedia of Quaternary Science, edited by: Elias, S. A., Elsevier Science, 2315-2336, https://doi.org/10.1016/B0-44-452747-8/00229-5, 2007.

McMorrow, J. M., Cutler, M. E. J., Evans, M. G., and AlRoichdi, A.: Hyperspectral indices for characterizing upland peat composition, Int. J. Remote Sens., 25, 313-325, https://doi.org/10.1080/0143116031000117065, 2004.

Missiaen, T., Murphy, S., Loncke, L., and Henriet, J. P.: Very high-resolution seismic mapping of shallow gas in the Belgian coastal zone, Cont. Shelf Res., 22, 2291-2301, https://doi.org/10.1016/S0278-4343(02)00056-0, 2002.

Morris, P. J., Swindles, G. T., Valdes, P. J., Ivanovic, R. F., Gregoire, L. J., Smith, M. W., Tarasov, L., Haywood, A. M., and Bacon, K. L.: Global peatland initiation driven by regionally asynchronous warming, P. Natl. Acad. Sci. USA, 115, 201717838, https://doi.org/10.1073/pnas.1717838115, 2018. 
Muller-Karger, F. E., Varela, R., Thunell, R., Luerssen, R., Hu, C., and Walsh, J. J.: The importance of continental margins in the global carbon cycle, Geophys. Res. Lett., 32, 1-4, https://doi.org/10.1029/2004GL021346, 2005.

Niemann, H., Elvert, M., Hovland, M., Orcutt, B., Judd, A., Suck, I., Gutt, J., Joye, S., Damm, E., Finster, K., and Boetius, A.: Methane emission and consumption at a North Sea gas seep (Tommeliten area), Biogeosciences, 2, 335-351, https://doi.org/10.5194/bg-2-335-2005, 2005.

Nobu, M. K., Dodsworth, J. A., Murugapiran, S. K., Rinke, C., Gies, E. A., Webster, G., Schwientek, P., Kille, P., Parkes, R. J., Sass, H., Jørgensen, B. B., Weightman, A. J., Liu, W. T., Hallam, S. J., Tsiamis, G., Woyke, T., and Hedlund, B. P.: Phylogeny and physiology of candidate phylum "Atribacteria" (OP9/JS1) inferred from cultivation-independent genomics, ISME J., 10, 273-286, https://doi.org/10.1038/ismej.2015.97, 2016.

Oksanen, A. J., Blanchet, F. G., Kindt, R., Legen-, P., Minchin, P. R., Hara, R. B. O., Simpson, G. L., Solymos, P., and Stevens, M. H. H.: Community Ecology Package, 263, https://doi.org/10.4135/9781412971874.n145, 2019.

Oppo, D., De Siena, L., and Kemp, D. B.: A record of seafloor methane seepage across the last 150 million years, Sci. Rep., 10, 1-12, https://doi.org/10.1038/s41598-020-59431-3, 2020.

Oremland, R. S. and Polcin, S.: Methanogenesis and Sulfate Reduction: Competitive and Noncompetitive Substrates in Estuarine Sediments, Appl. Environ. Microbiol., 44, 1270-1276, https://doi.org/10.1128/aem.44.6.1270-1276.1982, 1982.

Orsi, W. D., Vuillemin, A., Rodriguez, P., Coskun, Ö. K., GomezSaez, G. V, Lavik, G., Mohrholz, V., and Ferdelman, T. G.: Metabolic activity analyses demonstrate that Lokiarchaeon exhibits homoacetogenesis in sulfidic marine sediments, Nat. Microbiol., 5, 248-255, https://doi.org/10.1038/s41564-019-06303, 2020.

Parkes, R. J., Wellsbury, P., Mather, I. D., Cobb, S. J., Cragg, B. A., Hornibrook, E. R. C., and Horsfield, B.: Temperature activation of organic matter and minerals during burial has the potential to sustain the deep biosphere over geological timescales, Org. Geochem., 38, 845-852, https://doi.org/10.1016/j.orggeochem.2006.12.011, 2007.

Purdy, K. J., Munson, M. A., Nedwell, D. B., and Embley, T. M.: Comparison of the molecular diversity of the methanogenic community at the brackish and marine ends of a UK estuary, FEMS Microbiol. Ecol., 39, 17-21, https://doi.org/10.1016/S01686496(01)00188-X, 2002.

Reeburgh, W. S.: Oceanic methane biogeochemistry, Chem. Rev., 107, 486-513, https://doi.org/10.1021/cr050362v, 2007.

Rehder, G., Keir, R. S., Suess, E., and Pohlmann, T.: The multiple sources and patterns of methane in North Sea waters, Aquat. Geochem., 4, 403-427, https://doi.org/10.1023/A:1009644600833, 1998.

Reimer, P. J., Bard, E., Bayliss, A., Beck, J. W., Blackwell, P. G., Ramsey, C. B., Buck, C. E., Cheng, H., Edwards, R. L., Friedrich, M., Grootes, P. M., Guilderson, T. P., Haflidason, H., Hajdas, I., Hatté, C., Heaton, T. J., Hoffmann, D. L., Hogg, A. G., Hughen, K. A., Kaiser, K. F., Kromer, B., Manning, S. W., Niu, M., Reimer, R. W., Richards, D. A., Scott, E. M., Southon, J. R., Staff, R. A., Turney, C. S. M., and van der Plicht, J.: IntCal13 and Marine13 Radiocarbon Age Calibration
Curves 0-50,000 Years cal BP, Radiocarbon, 55, 1869-1887, https://doi.org/10.2458/azu_js_rc.55.16947, 2013.

Saunois, M., Stavert, A., Poulter, B., Bousquet, P., Canadell, J., Jackson, R., Raymond, P., Dlugokencky, E., Houweling, S., Patra, P., Ciais, P., Arora, V., Bastviken, D., Bergamaschi, P., Blake, D., Brailsford, G., Bruhwiler, L., Carlson, K., Carrol, M., Castaldi, S., Chandra, N., Crevoisier, C., Crill, P., Covey, K., Curry, C., Etiope, G., Frankenberg, C., Gedney, N., Hegglin, M., Höglund-Isaksson, L., Hugelius, G., Ishizawa, M., Ito, A., Janssens-Maenhout, G., Jensen, K., Joos, F., Kleinen, T., Krummel, P., Langenfelds, R., Laruelle, G., Liu, L., Machida, T., Maksyutov, S., McDonald, K., McNorton, J., Miller, P., Melton, J., Morino, I., Müller, J., Murguia-Flores, F., Naik, V., Niwa, Y., Noce, S., O’Doherty, S., Parker, R., Peng, C., Peng, S., Peters, G., Prigent, C., Prinn, R., Ramonet, M., Regnier, P., Riley, W., Rosentreter, J., Segers, A., Simpson, I., Shi, H., Smith, S., Steele, L. P., Thornton, B., Tian, H., Tohjima, Y., Tubiello, F., Tsuruta, A., Viovy, N., Voulgarakis, A., Weber, T., van Weele, M., van der Werf, G., Weiss, R., Worthy, D., Wunch, D., Yin, Y., Yoshida, Y., Zhang, W., Zhang, Z., Zhao, Y., Zheng, B., Zhu, Q., Zhu, Q., and Zhuang, Q.: The Global Methane Budget 2000-2017, Earth Syst. Sci. Data, 12, 1561-1623, https://doi.org/10.5194/essd-121561-2020, 2020.

Schloss, P. D., Westcott, S. L., Ryabin, T., Hall, J. R., Hartmann, M., Hollister, E. B., Lesniewski, R. A., Oakley, B. B., Parks, D. H., Robinson, C. J., Sahl, J. W., Stres, B., Thallinger, G. G., Van Horn, D. J., and Weber, C. F.: Introducing mothur: open-source, platform-independent, communitysupported software for describing and comparing microbial communities, Appl. Environ. Microbiol., 75, 7537-7541, https://doi.org/10.1128/AEM.01541-09, 2009.

Schneider von Deimling, J., Linke, P., Schmidt, M., and Rehder, G.: Ongoing methane discharge at well site $22 / 4 b$ (North Sea) and discovery of a spiral vortex bubble plume motion, Mar. Pet. Geol., 68, 718-730, https://doi.org/10.1016/j.marpetgeo.2015.07.026, 2015.

Schroot, B. M., Klaver, G. T., and Schüttenhelm, R. T. E.: Surface and subsurface expressions of gas seepage to the seabed - Examples from the Southern North Sea, Mar. Pet. Geol., 22, 499-515, https://doi.org/10.1016/j.marpetgeo.2004.08.007, 2005.

Sheng, Y., Smith, L. C., MacDonald, G. M., Kremenetski, K. V., Frey, K. E., Velichko, A. A., Lee, M., Beilman, D. W., and Dubinin, P.: A high-resolution GIS-based inventory of the west Siberian peat carbon pool, Global Biogeochem. Cy., 18, GB3004, https://doi.org/10.1029/2003GB002190, 2004.

Siebel, H. and During, H.: Beknopte mosflora van Nederland en België, KNNV, 2006.

Sousa, F. L., Neukirchen, S., Allen, J. F., Lane, N., and Martin, W. F.: Lokiarchaeon is hydrogen dependent, Nat. Microbiol., 1, 1416, https://doi.org/10.1038/nmicrobiol.2016.34, 2016.

Spang, A., Saw, J. H., Jørgensen, S. L., Zaremba-Niedzwiedzka, K., Martijn, J., Lind, A. E., Van Eijk, R., Schleper, C., Guy, L., and Ettema, T. J. G.: Complex archaea that bridge the gap between prokaryotes and eukaryotes, Nature, 521, 173-179, https://doi.org/10.1038/nature14447, 2015.

Spang, A., Stairs, C. W., Dombrowski, N., Eme, L., Lombard, J., Caceres, E. F., Greening, C., Baker, B. J., and Ettema, T. J. G.: Proposal of the reverse flow model for the origin of the eukaryotic cell based on comparative analyses of 
Asgard archaeal metabolism, Nat. Microbiol., 4, 1138-1148, https://doi.org/10.1038/s41564-019-0406-9, 2019.

Steinle, L., Schmidt, M., Bryant, L., Haeckel, M., Linke, P., Sommer, S., Zopfi, J., Lehmann, M. F., Treude, T., and Niemannn, H.: Linked sediment and water-column methanotrophy at a man-made gas blowout in the North Sea: Implications for methane budgeting in seasonally stratified shallow seas, Limnol. Oceanogr., 61, S367-S386, https://doi.org/10.1002/lno.10388, 2016.

Stocker, R.: Marine microbes see a sea of gradients, Science, 338, 628-633, https://doi.org/10.1126/science.1208929, 2012.

Takai, K. and Horikoshi, K.: Rapid detection and quantification of members of the archaeal community by quantitative PCR using fluorogenic probes, Appl. Environ. Microbiol., 66, 5066-5072, https://doi.org/10.1128/AEM.66.11.5066-5072.2000, 2000.

Thauer, R. K.: Anaerobic oxidation of methane with sulfate: On the reversibility of the reactions that are catalyzed by enzymes also involved in methanogenesis from $\mathrm{CO}_{2}$, Curr. Opin. Microbiol., 14, 292-299, https://doi.org/10.1016/j.mib.2011.03.003, 2011.

Tiemeyer, B., Albiac Borraz, E., Augustin, J., Bechtold, M., Beetz, S., Beyer, C., Drosler, M., Ebli, M., Eickenscheidt, T., Fiedler, S., Forster, C., Freibauer, A., Giebels, M., Glatzel, S., Heinichen, J., Hoffmann, M., Hoper, H., Jurasinski, G., Leiber-Sauheitl, K., Peichl-Brak, M., Rosskopf, N., Sommer, M., and Zeitz, J.: High emissions of greenhouse gases from grasslands on peat and other organic soils, Glob. Change Biol., 22, 4134-4149, https://doi.org/10.1111/gcb.13303, 2016.

Tobolski, K. and Ammann, B.: Macrofossils as records of plant responses to rapid Late Glacial climatic changes at three sites in the Swiss Alps, Palaeogeogr. Palaeocl., 159, 251-259, 2000.

Treat, C. C., Kleinen, T., Broothaerts, N., Dalton, A. S., Dommaine, R., Douglas, T. A., Drexler, J. Z., Finkelstein, S. A., Grosse, G., Hope, G., Hutchings, J., Jones, M. C., Kuhry, P., Lacourse, T., Lähteenoja, O., Loisel, J., Notebaert, B., Payne, R. J., Peteet, D. M., Sannel, A. B. K., Stelling, J. M., Strauss, J., Swindles, G. T., Talbot, J., Tarnocai, C., Verstraeten, G., Williams, C. J., Xia, Z., Yu, Z., Väliranta, M., Hättestrand, M., Alexanderson, H., and Brovkin, V.: Widespread global peatland establishment and persistence over the last 130,000 y, P. Natl. Acad. Sci. USA, 116, 4822-4827, https://doi.org/10.1073/pnas.1813305116, 2019.

Van den Bos, R. M.: Human influence on carbon fluxes in coastal peatlands; process analysis, quantification and prediction, Vrije Universiteit, Amsterdam, 2003.

Van Der Meulen, M. J., Doornenbal, J. C., Gunnink, J. L., Stafleu, J., Schokker, J., Vernes, R. W., Van Geer, F. C., Van Gessel, S. F., Van Heteren, S., Van Leeuwen, R. J. W., Bakker, M. A. J., Bogaard, P. J. F., Busschers, F. S., Griffioen, J., Gruijters, S. H. L. L., Kiden, P., Schroot, B. M., Simmelink, H. J., Van Berkel, W. O., Van Der Krogt, R. A. A., Westerhoff, W. E., and Van Daalen, T. M.: 3D geology in a 2D country: Perspectives for geological surveying in the Netherlands, Geol. Mijnbouw/Netherlands J. Geosci., 92, 217-241, https://doi.org/10.1017/S0016774600000184, 2013.

van Geel, B., Brinkkemper, O., van Reenen, G. B. A., Van der Putten, N. N. L., Sybenga, J. E., Soonius, C., Kooijman, A. M., Hakbijl, T., and Gosling, W. D.: Multicore Study of Upper Holocene Mire Development in West-Frisia, Northern Netherlands: Ecological and Archaeological Aspects, Quaternary, 3, https://doi.org/10.3390/quat3020012, 2020.
Venables, W. and Ripley, B.: Modern applied statistics with S, 4th Edn., Springer, New York, 2002.

Vink, A., Steffen, H., Reinhardt, L., and Kaufmann, G.: Holocene relative sea-level change, isostatic subsidence and the radial viscosity structure of the mantle of northwest Europe (Belgium, the Netherlands, Germany, southern North Sea), Quaternary Sci. Rev., 26, 3249-3275, https://doi.org/10.1016/j.quascirev.2007.07.014, 2007.

Wasmund, K., Schreiber, L., Lloyd, K. G., Petersen, D. G., Schramm, A., Stepanauskas, R., Jørgensen, B. B., and Adrian, L.: Genome sequencing of a single cell of the widely distributed marine subsurface Dehalococcoidia, phylum Chloroflexi, ISME J., 8, 383-397, https://doi.org/10.1038/ismej.2013.143, 2014.

Weber, T., Wiseman, N. A., and Kock, A.: Global ocean methane emissions dominated by shallow coastal waters, Nat. Commun., 10, 1-10, https://doi.org/10.1038/s41467-019-12541-7, 2019.

Webster, G., Yarram, L., Freese, E., Köster, J., Sass, H., Parkes, R. J., and Weightman, A. J.: Distribution of candidate division JS1 and other Bacteria in tidal sediments of the German Wadden Sea using targeted 16S rRNA gene PCR-DGGE, FEMS Microbiol. Ecol., 62, 78-89, https://doi.org/10.1111/j.15746941.2007.00372.x, 2007.

Wilms, R., Sass, H., Kopke, B., and Koster, J.: Specific bacterial, archaeal, and eukaryotic communities in tidal-flat sediments along a vertical profile of several meters, Appl. Environ. Microbiol., 72, 2756-2764, https://doi.org/10.1128/AEM.72.4.2756-2764.2006, 2006.

Wolters, S., Zeiler, M., and Bungenstock, F.: Early Holocene environmental history of sunken landscapes: Pollen, plant macrofossil and geochemical analyses from the Borkum Riffgrund, southern North Sea, Int. J. Earth Sci., 99, 1707-1719, https://doi.org/10.1007/s00531-009-0477-6, 2010.

$\mathrm{Xu}$, J., Morris, P. J., Liu, J., and Holden, J.: PEATMAP: Refining estimates of global peatland distribution based on a meta-analysis, Catena, 160, 134-140, https://doi.org/10.1016/j.catena.2017.09.010, 2018.

Yu, T., Wu, W., Liang, W., Lever, M. A., Hinrichs, K. U., and Wang, F.: Growth of sedimentary Bathyarchaeota on lignin as an energy source, P. Natl. Acad. Sci. USA, 115, 6022-6027, https://doi.org/10.1073/pnas.1718854115, 2018.

Yu, Z., Loisel, J., Brosseau, D. P., Beilman, D. W., and Hunt, S. J.: Global peatland dynamics since the Last Glacial Maximum, Geophys. Res. Lett., 37, 3-8, https://doi.org/10.1029/2010GL043584, 2010.

Zhou, Z., Pan, J., Wang, F., Gu, J.-D., and Li, M.: Bathyarchaeota: globally distributed metabolic generalists in anoxic environments, FEMS Microbiol. Rev., 42, 639-655, https://doi.org/10.1093/femsre/fuy023, 2018.

Zhuang, G. C., Heuer, V. B., Lazar, C. S., Goldhammer, T., Wendt, J., Samarkin, V. A., Elvert, M., Teske, A. P., Joye, S. B., and Hinrichs, K. U.: Relative importance of methylotrophic methanogenesis in sediments of the Western Mediterranean Sea, Geochim. Cosmochim. Ac., 224, 171-186, https://doi.org/10.1016/j.gca.2017.12.024, 2018. 